\title{
New Insights into Immunotherapy Strategies for Treating Autoimmune Diabetes
}

\author{
Miriam Cabello-Olmo ${ }^{1} @$, Miriam Araña ${ }^{1} @$, Ilian Radichev ${ }^{2}$, Paul Smith ${ }^{3}$, Eduardo Huarte ${ }^{3, *}$ \\ and Miguel Barajas ${ }^{1, *}$ \\ 1 Biochemistry Area, Health Science Department, Faculty of Health Sciences, Public University of Navarra, \\ 31008 Pamplona, Spain; miriamcabelloolmo@gmail.com (M.C.-O.); miriam.arana@unavarra.es (M.A.) \\ 2 Diabetes Research Group at Sanford Research, Sioux Falls, SD 57104, USA; \\ Ilian.Radichev@SanfordHealth.org \\ 3 Incyte Corporation, Wilmington, DE 19803, USA; PSmith@incyte.com \\ * Correspondence: EHuarte@incyte.com (E.H.); miguel.barajas@unavarra.es (M.B.)
}

Received: 29 August 2019; Accepted: 20 September 2019; Published: 26 September 2019

\begin{abstract}
Type 1 diabetes mellitus (T1D) is an autoimmune illness that affects millions of patients worldwide. The main characteristic of this disease is the destruction of pancreatic insulin-producing beta cells that occurs due to the aberrant activation of different immune effector cells. Currently, T1D is treated by lifelong administration of novel versions of insulin that have been developed recently; however, new approaches that could address the underlying mechanisms responsible for beta cell destruction have been extensively investigated. The strategies based on immunotherapies have recently been incorporated into a panel of existing treatments for T1D, in order to block T-cell responses against beta cell antigens that are very common during the onset and development of T1D. However, a complete preservation of beta cell mass as well as insulin independency is still elusive. As a result, there is no existing T1D targeted immunotherapy able to replace standard insulin administration. Presently, a number of novel therapy strategies are pursuing the goals of beta cell protection and normoglycemia. In the present review we explore the current state of immunotherapy in T1D by highlighting the most important studies in this field, and envision novel strategies that could be used to treat T1D in the future.
\end{abstract}

Keywords: diabetes; autoimmunity; insulin; immunotherapy and clinical trials

\section{Introduction}

Type 1 diabetes mellitus (T1D) is a pathology emerging from the selective elimination of pancreatic insulin-producing beta cells mediated by an autoimmune defect. Consequently, the main characteristic of this disease that occurs in its advanced stages is hyperglycemia. This form of diabetes accounts for approximately $5-10 \%$ of all diabetic patients.

The prevalence of this pathology indicates that more than 500,000 children suffer from type 1 diabetes worldwide, mostly in North America and Europe [1]. However, the epidemiologic studies suggest that the incidence of T1D has increased markedly in recent years [2]. In 2017, the International Diabetes Federation (IDF; https://diabetesatlas.org) declared 132,600 newly diagnosed T1D cases worldwide.

\subsection{Genetics of T1D}

One of the main characteristics of T1D is the loss of beta cell tolerance, a process that involves different factors $[3,4]$ including genetic associations with human leukocyte antigen haplotypes (HLA) and several beta cell-specific genes [5]. 
T1D is described as an inflammatory disease in which the infiltration of the pancreatic islets with a number of immune cell types $\left(\mathrm{CD}^{+}\right.$and $\mathrm{CD} 8^{+} \mathrm{T}$-cells, macrophages, dendritic cells (DC), and $\mathrm{B}$ cells) play a significant role [6]. The progression of islet infiltrates promotes beta cell elimination that ultimately results in the onset of diabetes.

While having some benefits, the transplantation of pancreas or pancreatic islets (Edmonton Protocol) [7] have had limited success due to the insufficient number of donors and the reactivation of the autoimmunity status despite immunosuppression protocols. Additionally, pancreas transplants have been demonstrated to be only partially successful [8].

\subsection{Immunological Mechanisms Involved in T1D Pathogenesis}

The progression of T1D can be divided into three critical stages $[9,10]$. At the "first stage", which may take place through a long period of time, individuals develop beta cell autoimmunity, identified by serum autoantibodies. The most frequent autoantibodies in T1D patients are those against GAD (GAD65), the tyrosine phosphatases IA-2 and IA-2 $\beta$, zinc transporter 8 (ZnT8), and insulin [11]. Those epitopes can induce the activation of $\mathrm{CD} 4^{+}$and $\mathrm{CD} 8^{+} \mathrm{T}$-cells, which are the main mediators of beta cell destruction.

The presence of diabetes autoantibodies plays an important role in the identification of preclinical stages of T1D. The TrialNet TN01 has analyzed the importance of the autoantibodies markers for the detection of diabetes [12]. Five percent of the people screened through this study were found to present blood autoantibody. This study also determined that $95 \%$ of patients that progress to symptomatic T1D were autoantibody positive by the age of 5 years [13].

The identification of autoantibodies in the TEDDY (The Environmental Determinants of Diabetes in the Young) study showed a peak between 2 and 9 years of age [14]. Individuals that demonstrate the presence of at least two different autoantibodies have a significant chance of developing T1D [12,15].

Additionally, different HLA haplotypes were identified to be either protective or predisposing to diabetes development [16]. When autoreactive $\mathrm{CD}^{+}$and $\mathrm{CD} 8^{+} \mathrm{T}$-cells begin to extinguish beta cells, the insulin levels start to decrease, which initiate the "second stage" of the T1D. At this stage, the main strategy for T1D treatment would be to suppress beta cell autoimmunity along with protection of the remaining beta cell mass. Different studies have demonstrated that at the time of diagnosis, which overlap with the second stage, there are still residual beta cells present (Clinical trial NCT01030861) [17]. Administration of immunosuppressive drugs in children with new onset of T1D can delay or reverse diabetes progression; however, immunosuppression can also result in organ toxicity. The diabetes progression resumes once the treatment is withdrawn [18].

The "third stage" of T1D occurs in long-term patients. At this stage, the main objective is to ensure the functionality of the remaining beta cell. The studies have shown that following the disease onset there is a considerable reduction in C-peptide levels, a short polypeptide that connects insulin's chains in the proinsulin molecule and can be used as a surrogate of how much insulin is produced (Clinical trial NCT01030861) [17]. The maintenance of a high beta cell number could help in the control of hyperglycemia as well as to reduce the comorbidities of the disease.

It has been demonstrated that $\mathrm{CD} 8^{+}$and $\mathrm{CD} 4^{+} \mathrm{T}$-cells, macrophages, and $\mathrm{B}$ cells are present in human cadaveric T1D pancreata [12,19]. However, the lack of insulitis in some T1D cadaveric pancreata samples underlines the heterogeneity of the disease [20] which could be one of the reasons why immunotherapies have not been fully effective in T1D patients.

Different immunotherapies have been proposed for all three stages of T1D. One approach involves the manipulation of the immune response, by using antibodies that target specific immune mediators. Another approach takes advantage of beta cell antigen-specific treatments. Interestingly, a treatment based on oral insulin administration demonstrated a delay in the diabetes onset in Non-Obese Diabetic (NOD) mice [21], an animal model which has been heavily used to study the progression and pathogenesis of T1D, and which we will describe in the next section. 


\subsection{Animal Models of T1D}

Two different animal models have mostly been used in the field of T1D research: The NOD mouse and Bio-breeding (BB) rat. Both models exhibit the main symptoms of diabetes: Glycosuria, polyuria, weight loss, and islet of Langerhans-lymphocytic infiltration [22,23]. However, due to the implication of the T-cell compartment in the pathogenesis of T1D, the NOD model has been preferably used for the study of the diabetogenic T-cells development [24]. NOD mice show similar characteristics to human diabetes, summarized in Table 1.

NOD mice were originally generated in the Cataract Shionogi (CTS) strain [22]. Cell infiltration in the pancreas of NOD mice can be observed at as early as 3 weeks of age. This process includes the recruitment of different innate immune cells into the islets of Langerhans including macrophages and neutrophils, prior to the infiltration of the lymphocytes $[25,26]$. Although the presence of autoreactive T-cells is initially low, their numbers gradually increase, due to the recognition of certain diabetes-specific autoantigens and become activated, initiating the elimination of insulin-producing beta cells. Despite the focus of T1D research on T-cell-mediated beta-cell destruction, there are studies showing that B cells also play an important role in the diabetes onset [27].

The NOD mouse model has provided valuable information regarding the role of the immune cells in diabetes development. Furthermore, NOD mice have provided a unique research tool in order to explore immunotherapy treatments (i.e., CTLA4-Ig, anti-CD40 antibodies, and IL-4 or IL-10 treatment), as has been exhaustively reviewed by Shoda et al. [28]. However, most of the immune-interventions that have shown promise in the NOD mouse model failed to demonstrate similar impact on human disease. For this reason, the attempts to humanize NOD mice [29] might facilitate the research that would eventually translate into successful immunotherapy clinical trials.

Additionally, some external factors also play an important role in T1D development. The studies in monozygotic twins have demonstrated a lack of concordance suggesting the importance of environmental factors in the T1D progress. Many of those factors have been involved in modifying diabetes susceptibility in NOD mice, including changes in the gut microbiota [30-32]. The interaction of innate immune components with the gut microbiota represents a hot topic in the field of T1D research. We will deepen this aspect in Section 6.2.

Apart from the previously mentioned mouse models, another useful model is the DO11.10×RIPmOVA (DORmO) mouse model, where RIPmOva animals (mice that express membrane-bound OVA in thymus and pancreas) are crossed with DO11 animals expressing an OVA-specific MHC-II TCR. Somehow surprisingly, these double-transgenic animals generate large numbers of islet specific functional $\mathrm{T}_{\text {reg }}$ cells (see Section 2.3), but spontaneously develop T1D by week 20 . Therefore, the DORmO model is uniquely suited to study $\mathrm{T}_{\text {reg }}$ role in T1D initiation/progression [33,34]. 
Table 1. Autoimmune diabetes developed by NOD mouse compared to human T1D.

\begin{tabular}{ccc}
\hline & NOD & Human \\
\hline Age at onset & $>10$ weeks & $>6$ months-late adolescence \\
Genetic susceptibility & MHC most important & HLost important \\
Autoantigens & Insulin, GAD, IA-2, IA-2b, ZnT8, IGRP, IAPP, HSP60, & Carboxypetidase H \\
Insulitis & DCs, Macrophages, B cells, NK cells, CD4 \& CD8 T cells & DCs, Macrophages, B cells, NK cells, CD4 \& CD8 T cells \\
Ketoacidosis & Mild & Severe \\
Gender effect & Females predominantly affected & Males and females almost equally affected \\
\hline
\end{tabular}




\subsection{Present State of T1D Immunotherapy}

Current strategies for T1D immunotherapies could be classified as antigen-independent and antigen-dependent. Antigen-independent (non-antigen specific) interventions include: drugs that induce immunosuppression, antibody-based therapies that allow the depletion of polyclonal B or T cells [35], cytokine-based strategies [36], and the increase of tolerogenic DC [37], and polyclonal $\mathrm{T}_{\text {reg }}$ cell numbers [34].

Antigen-dependent (antigen-specific) strategies involve the use of beta cell-derived autoantigen-based vaccines, adoptive transfer strategies and specific abrogation of autoreactive T-cell clone by targeting antigen presentation mechanisms [38,39].

The combination of different interventions based in immunotherapy treatments is considered the most effective strategy due to the complexity of T1D [40].

In the next sections, we will analyze the strategies of immunotherapy that are currently used for treatment and prevention of T1D (summarized in Table 2 and Figure 1).

Table 2. Strategies for the treatment of T1D.

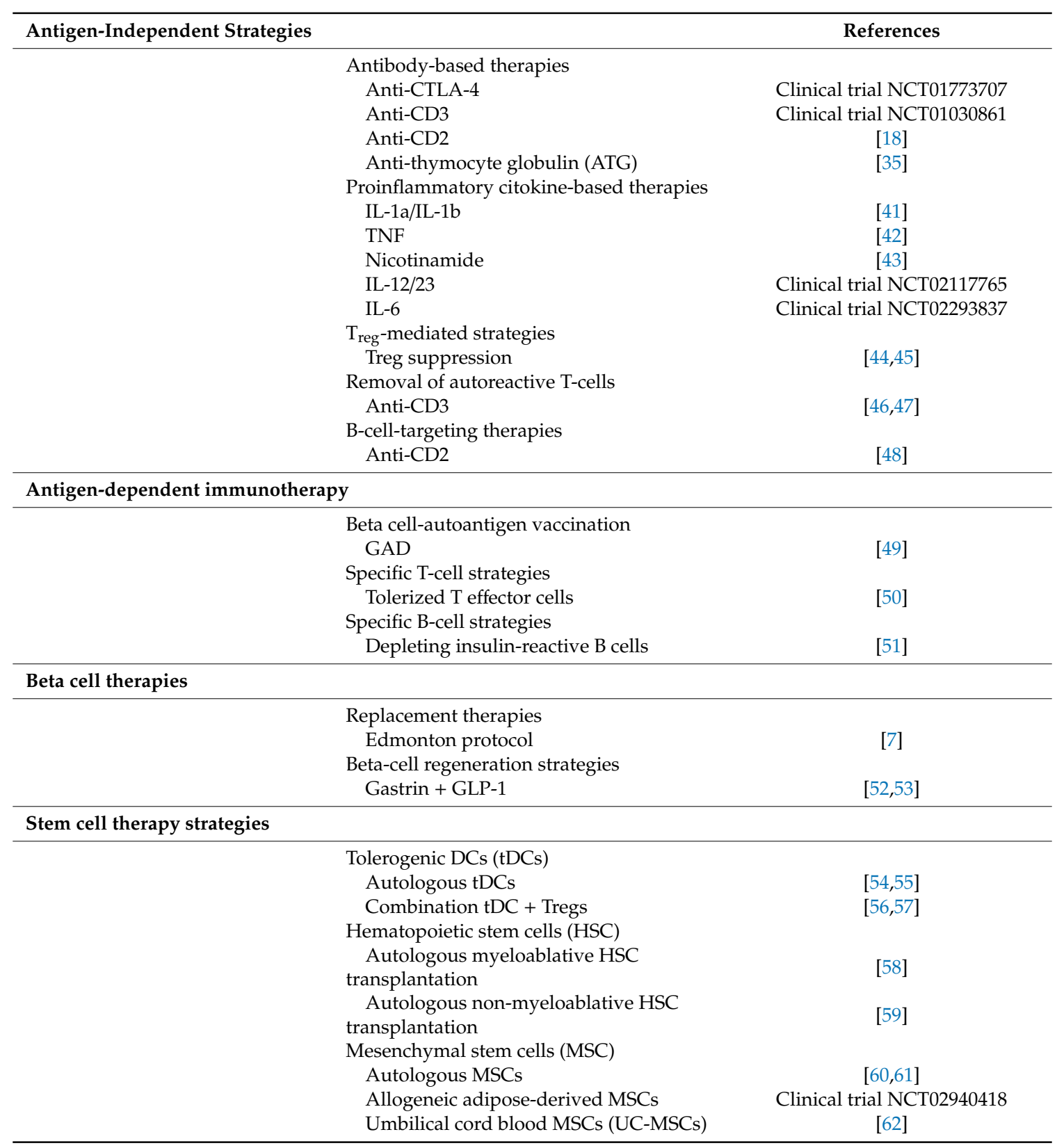




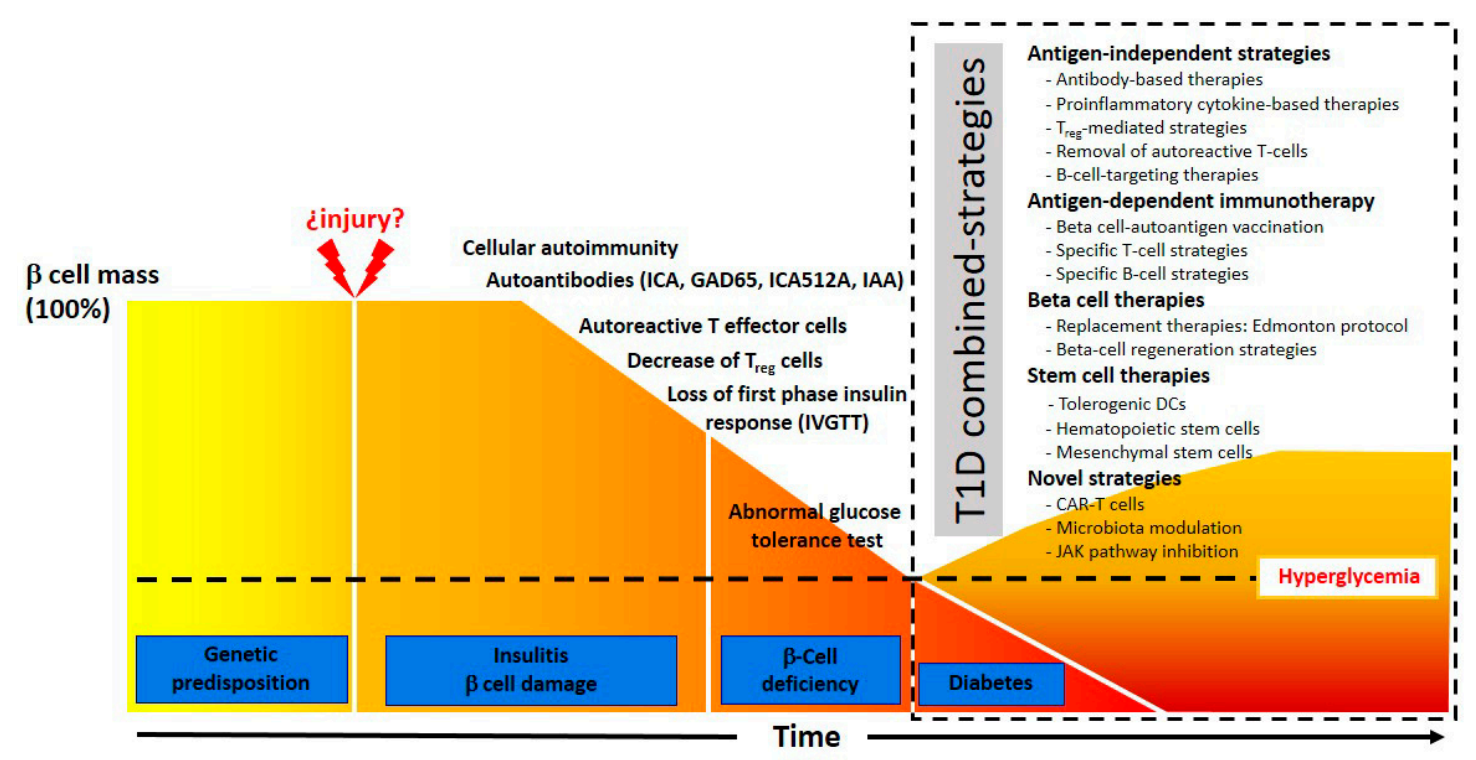

Figure 1. Progression of T1D and combined-strategies for T1D treatment.

\section{Antigen-Independent Strategies}

\subsection{Antibody-Based Therapies}

The activation of T-cells is controlled by various costimulatory pathways which could be positive or negative. For example, signaling through CTLA4 induces an anergic state in naïve T-cells, and therefore Abatacept, a fusion protein composed of the Fc portion of human IgG1 fused to the extracellular domain of the CTLA4, is used for treatment of rheumatoid arthritis [63]. In a recent clinical trial, abatacept has demonstrated potential against T1D by delaying C-peptide exhaustion in T1D patients [41]. The clinical trial TrialNet is analyzing the benefits of abatacept in the delay of early T1D onset (Clinical trial NCT01773707; www.clinicaltrials.gov).

Anti-CD3 monoclonal antibodies that target CD3/T-cell receptor (TCR) complex, blocking the union of CD3 with TCR and rendering an anergic state of the T-cells have also been tested in T1D patients. Teplizumab and otelixizumab, two of the main clinically approved anti-CD3 antibodies, have demonstrated some efficacy in T1D patients [42]. Teplizumab treatment induces a delay in C-peptide decay in treated T1D patients. In this study AbATE, 2 week-teplizumab treatment resulted in C-peptide preservation [17] [Clinical trial NCT01030861; www.clinicaltrials.gov]. The main results from this clinical trial are expected to be released at the end of 2019.

Among the selective ablation of $\mathrm{T}$ effector cells, the elimination of memory T-cells would also be necessary in order to obtain long-lasting results. This could be achieved by inhibiting CD2 signaling. The anti-CD2 fusion protein Alefacept efficiently blocks T-cell activation inducing apoptosis of both memory and effector T lymphocytes. Unfortunately, only a modest trend towards preserving C-peptide levels was achieved when this hypothesis was tested during the clinical trial T1DAL, which included patients at late stage of T1D [18].

Lastly, anti-thymocyte globulin (ATG) have been described to be able to deplete activated T-cells. ATG used in low doses in combination with granulocyte colony-stimulating factor (G-CSF) showed that it is safe and can induce protection of beta cell mass [43]. Later clinical trials demonstrated that G-CSF by itself did not provide any additional benefits [64].

\subsection{Proinflammatory Cytokine-Based Treatments}

The role of inflammation and proinflammatory cytokines have been long known to have a role in T1D development [65]. Inhibition of expression of those molecules can induce important changes 
in pancreatic beta cells [44]. Such strategy was clinically used for treatment of other autoimmune diseases [65].

Interleukin (IL)- $1 \alpha$ and IL-1 $\beta$ are important immunomodulators expressed by monocytes that can induce a toxicity on beta cells [45]. Anti-IL-1 administration for rheumatoid arthritis has been proven to be well tolerated in patients [46]. IL-1 is also involved in T1D progression by activating T helper cells, and improving the number of circulating memory T-cells [47]. A clinical trial performed on T1D patients suggested that IL-1 inhibition could induce a preservation of pancreatic beta cells [66].

Another cytokine that plays an important role as an intermediary molecule in autoimmune diseases is tumor necrosis factor $\alpha$ (TNF- $\alpha$ ). Therefore, the blockade of TNF- $\alpha$ has been tested as a treatment of autoimmunity. Regarding T1D, patients that were treated with Etanercept (recombinant TNF- $\alpha$ receptor-IgG fusion protein) had improved preservation of beta cell mass (assessed by the C-peptide levels) and decreased glycated hemoglobin levels [48].

The ability of nicotinamide alone or in combination with vitamin $\mathrm{E}$ to preserve functionality of remaining beta cells has also been tested. Both treatments proved to be effective in retaining the basal secretion of C-peptide [67].

The IL-12/23 cytokine pathway, which is involved in the induction of inflammatory cytokines and pathogenic T-cell activation, was also considered as a potential therapy for T1D therapy. The application of Ustekinumab (IL-12/23 blocking molecule) has been tested in patients with T1D (UST1D clinical trial) (Clinical trial NCT02117765; www.clinicaltrials.gov).

Overexpression of IL-6 was noticed in a subset of T1D patients [68]. As a result, anti-IL-6 therapy, which is also tested in managing arthritis and systemic juvenile idiopathic arthritis [69], was initiated. Currently, the clinical trial EXTEND (Clinical trial NCT02293837; www.clinicaltrials.gov) is examining whether the blockade of IL-6 signaling (tocilizumab, an anti-IL-6 receptor antibody)) can induce a protection of beta cell function in T1D patients (ages 6 to 17 years) is ongoing.

Taking all the data together, cytokine inhibition is emerging as a viable supplementary approach in order to achieve durable therapeutic efficacy of T1D treatment.

\section{3. $T_{\text {reg-Mediated Strategies }}$}

$\mathrm{T}_{\text {regs }}$ have also been involved in the pathophysiology of T1D [70]. Bluestone and colleagues examined the role of expanded autologous polyclonal $\mathrm{T}_{\text {regs }}$ in the treatment of T1D patients [70]. In this clinical trial, autologous $\mathrm{T}_{\text {reg }}$ infusions were safe, but did not modify the course of the disease. Other clinical trials have also evaluated the effects of low doses of IL-2 on $\mathrm{T}_{\text {reg }}$ activity [71]. Although IL-2 was able to increase the total number of $\mathrm{T}_{\text {reg, }}$, this did not result in better glycemic control.

Intriguingly, recently published data has shown that blocking extracellular deposits of the polysaccharide hyaluronan (HA) (frequently observed in T1D patients [72]) reduced diabetes in two different mouse models by significantly enhancing the percentage of $\mathrm{T}_{\text {reg }}$ in pancreatic islets and preventing further $\beta$ cell destruction [34].

\subsection{Removal of Autoreactive T-cells}

Targeted depletion of autoreactive T-cells in T1D patients is an approach with great potential, as it aims to eliminate effector T-cells responsible for the destruction of pancreatic beta cells. Treatment of NOD mice with anti-CD3 antibodies was shown to induce anergy in T-cells [49]. Additionally, elevated high counts of $T_{\text {reg }}$ cells were observed in patients administered with anti-CD3. A clinical trial performed with T1D patients showed reduced insulin requirements after treatment with the anti-CD3 antibody [42,73]. No severe adverse events were observed, and even mild sides effects were rarely reported. These results suggest that anti-CD3 antibody treatment can be considered as a potential treatment for T1D [49]. 


\subsection{B-Cell-Targeting Therapies}

Since, B cells were implicated to take part in beta cell destruction through autoantibodies production, targeting of B cells in T1D settings has also been studied. The elimination of B cells in NOD mice prevented the accumulation of auto-antibodies, thus averting diabetes onset [74]. T1D patients treated with anti-CD20 antibodies showed higher C-peptide levels and lower insulin dependency when compared to the placebo group. However, this strategy does not seem to completely prevent C-peptide decay [50,75].

\section{Antigen-Dependent Immunotherapy}

In contrast to antigen-independent strategies, autoantigen-targeting treatments of T1D could modulate specifically T1D-related autoimmunity while preserving the normal immune homeostasis. The main objectives of antigen-specific therapies is to induce tolerance of autoreactive $\mathrm{T}$ effector cells and expansion of autoantigen-specific $\mathrm{T}_{\text {reg }}$ cells $[38,39]$.

\subsection{Beta Cell-Autoantigen Vaccination}

The exposure of specific antigens to naïve T-cells could induce immune tolerance to that antigen. According to current knowledge of T1D progression, we can hypothesize that antigens derived from beta cells that are applied in a non-inflammatory context might modulate autoreactive T-cells, resulting in beta cell preservation [76]. This paradigm has led to developing novel vaccination strategies to achieve the induction of T-cell tolerance against specific autoantigens. The well-known T cell epitopes against insulin and glutamic acid decarboxylase (GAD) have been extensively studied [51], demonstrating that C19-A2 proinsulin peptide could modulate autoreactive $\mathrm{CD} 4^{+} \mathrm{T}$-cells in patients with specific class II allele [77]. The administration of this peptide in recently diagnosed T1D patients resulted in the exhibition of higher C-peptide levels without symptoms of systemic or local hypersensibility [78].

Additionally, another T1D autoantigen, GAD65, was targeted in NOD mice in order to reduce the number of GAD65-specific T effector cells [79]. Normoglycemia was achieved in 70\% of NOD mice, and in $80 \%$ of them normoglycemia persisted in long-term post-antigen administration.

Despite the successful results observed with vaccination strategies in NOD mice, the dissimilarities in autoantigens between human and mice and the heterogeneity of T1D in humans makes this strategy not very suitable for clinical application [52].

\subsection{Specific T-Cell Strategies}

The dysfunctional imbalance of $\mathrm{T}_{\text {reg }}$ to $\mathrm{T}$ effector cells is an important factor determining the onset of T1D [80]. CD8 ${ }^{+}$T-cell activation is a process mediated by the presentation of specific epitopes from professional antigen-presenting cells (APCs) as DCs appear to be the principal APCs for the CD8 ${ }^{+}$ T-cell [81]. The process depends on $\mathrm{CD}^{+}{ }^{+} \mathrm{T}$-cells' interaction that induce the activation of specific subsets of $\mathrm{CD}^{+} \mathrm{T}$-cells which in turn is responsible for initiating islets' beta cell destruction [53]. The process of achieving self-tolerant $\mathrm{T}$ effector cells could be through use of either the whole antigen or specific peptides. However, success in tolerization of $\mathrm{T}$ effector cells depends on different factors, especially the identification of the autoantigen that drives this process. In order to prevent beta cell destruction, the most relevant $\mathrm{T}$ effector clones have to be deleted.

\subsection{Specific B-Cell Strategies}

The strategy based on the abrogation of non-specific B cells has not been very effective. However, inhibition of specific autoantigen B cells by depletion of insulin-reactive B cells, is a promising alternative [82]. Insulin-specific B cells elude the immune control in NOD mice responding to insulin by increasing the expression of costimulatory molecules during the crosspriming of effector T-cells. 


\section{Beta Cell Therapies}

\subsection{Replacement Therapies: Edmonton Protocol}

The Edmonton protocol has shown the value of islet transplantation in addressing insulin regulation in T1D patients [7]. According to this protocol, pancreatic islets obtained from cadaveric donors are infused into immunosuppressed T1D patients.

Trials conducted before 1990 using single islet infusions were partially successful, as they resulted in lower insulin needs and higher C-peptide levels; however, no additional steps to increase the net islet mass of the transplant had been taken in any of those trials [54].

Islet transplantation protocols became a promising therapy for type 1 diabetes thanks to the introduction of the Edmonton Protocol in 2000. Today this method is the only therapy that can reach glycemic control without the administration of insulin [55]. Transplantation of pancreatic islets has several advantages over the transplantation of a complete pancreas, since it involves only a minor surgical procedure with low morbidity and mortality, and a significantly lower cost. The main advantage of islet transplantation protocols over conventional insulin therapy is that transplanted islets are more efficient in maintaining normal blood glucose levels without producing excess insulin that could lead to episodes of hypoglycemia.

Modifications of the Edmonton Protocol based on a new immunosuppression regimen have prevented the use of corticosteroids, allowing the application of a unique combination therapy based on anti-interleukin- 2 receptor antibodies along with the immunosuppressant drugs sirolimus and tacrolimus. The main advantage of this combination treatment is low beta cells toxicity. Islet transplantation has shown some success regarding insulin independence both in the short and long term $[55,83]$ as much of the variability in the results obtained with the Edmonton Protocol is associated with factors related to both the organ donor and the recipient.

Although the benefits of the islet transplantation protocol are unquestionable, among the concerns for standardization of this strategy are the large number of islets that have to be transplanted and the adverse effects derived from the immunosuppression regimen. The first problem could be addressed by using stem cells that, under the adequate differentiation protocol, are able to differentiate into glucose sensitive insulin-producing cells (see Section 5.3).

\subsection{Beta-Cell Regeneration Strategies}

Gastrin and GLP-1 have a synergistic effect in inducing the regeneration and differentiation of beta cells [56,57]. In the NOD mouse model, the addition of both molecules resulted in increasing of beta-cell mass [58]. In addition, the combination therapy with DPP-4 inhibitors, (to increase GLP-1 levels), and proton pump inhibitors (PPIs; to increase gastrin levels), increased C-peptide levels and insulin secretion, and restored the normoglycemia in NOD mice [56]. In humans, the study REPAIR-T1D analyzed the effect of one-year similar treatment using a combination of sitagliptin (DPP-4 inhibitor) plus lansoprazole (PPIs inhibitor) in T1D patients [60]. However, no differences in C-peptide levels were observed between treated vs. placebo groups [60]. The authors claim that the increase in gastrin concentrations and GLP-1 were low, resulting in non-efficient treatment. Further clinical trials will be required in order to determine the role of gastrin and GLP-1 combination therapy.

\section{Stem Cell Therapy Strategies}

\subsection{Tolerogenic DCs}

Although various cell types have been studied as potential targets for T1D treatment, dendritic cells attracted special interest. However, clinical trials in which T1D patients received autologous DCs showed limited results. In these clinical trials, DCs were infused via abdominal intradermal injections every 2 weeks [61]. Although the treatment was well tolerated, no significant differences on glycaemia were observed. 
Previous studies demonstrated, that dendritic cells, alone or via different effector cells, such as $\mathrm{T}_{\text {regs }}$ and B-regulatory cells $\left(\mathrm{B}_{\text {reg }}\right)$, could play an important role in the activation status of autoreactive $\mathrm{CD}^{+}$cytotoxic T-cells (CTL) as well as influence the balance between T-helper cells (Th1 and Th2) and effector cell populations [59]. Tolerogenic DC ( $t D C s)$ populations have been used in different clinical trials for treatment of autoimmune diseases, including T1D [61,84]. The results of those studies suggested that $\mathrm{tDCs}$ remain at the administration site promoting the generation of a lymphoid stroma tissue which in turn allows the increase of $\mathrm{FoxP}^{+} \mathrm{T}_{\text {regs }}$ [85].

The synergistic inter-relationship of tDCs and $\mathrm{T}_{\text {regs }}$ allows them to generate a very powerful tolerogenic state. Co-administration of $\mathrm{tDC}$ and $\mathrm{T}_{\text {regs }}$, would allow stabilization of Foxp3 expression and would elevate the levels of IL-10, TGF- $\beta$, and retinoic acid by tDCs $[86,87]$. The tolerogenic state of the tDC would be increased via cell-cell interactions or through paracrine mechanisms. This combination strategy may change the paradigm of how autoimmune diseases are being treated, addressing the disproportion of the immune effectors generated during the disease-onset.

\subsection{Hematopoietic Stem Cells (HSC)}

Although immune dysfunctions linked to T1D are complex, Voltarelli and colleagues published an innovative research, where newly diagnosed T1D patients enrolled in a phase $1 / 2$ clinical trial received immunosuppression treatment together with the infusion of autologous HSCs. The results obtained were promising; almost all patients did not require insulin injections for 6 months as their C-peptide levels stayed stable and the anti-GAD auto-antibodies levels were diminished [88].

In two recent prospective non-randomized trials, most patients showed no need for insulin administration after HSC transplantation $[89,90]$. The results of those studies showed that even 4 years post-transplantation, the C-peptide levels were still significantly higher than pre-transplant ones [89].

Recently, the results from a study using autologous non-myeloablative HSC transplantation were published [62]. Fifty-nine percent of the patients included in this clinical trial did not require insulin administration while 32\% remained insulin-independent for at least 4 years [62].

Most of the patients included in the autologous HSC-transplantation clinical trials presented limited side effects. Only one clinical trial declared a patient death due to Pseudomonas aeruginosa sepsis [89].

Although the adverse effects related to immunosuppression protocol limit this alternative treatment, the administration of autologous HSC remains an exciting way forward in the task to find a cure for T1D.

\subsection{Mesenchymal Stem Cells}

Mesenchymal stem cells (MSCs) are stromal stem cells that play important roles in tissue repair and regeneration [91]. MSCs express specific antigen biomarkers (MHC I, CD90, CD105, and CD73) that enable their identification by flow cytometry techniques. MSCs have proven to be very promising in regenerative medicine thanks to their ability to give rise to different cell types, such as adipocytes, chondrocytes, and osteoblasts, making it possible to replace damaged tissues. [92]. In addition, MSC can be recruited from other injured tissues, such as ischemic heart or pancreas [92,93]. For this reason, MSCs are representing a new approach that will help the promotion of the integration of stem cell transplants in regenerative medicine protocols [94].

MSCs have been used to treat T1D patients and showed promising results in maintaining blood C-peptide levels [95]. However, no differences were observed for insulin requirements when compared with the non-treated group during the study.

The biological properties of MSCs regarding their potential to control aberrant immune response were demonstrated in NOD mouse model [96,97]. In Uppsala University Hospital's sponsored clinical trial, in which T1D patients were transplanted with autologous MSCs, treated patients exhibited a better maintenance of C-peptide levels [96]. Umbilical cord blood MSCs (UC-MSCs) were also tested in combination with autologous mononuclear cells derived from bone marrow (aBM-MNC) in another 
clinical trial. The results of this study showed that the infusion of aBM-MNC induces a $30 \%$ reduction of insulin requirements [98]. Nowadays, many trials are trying to test the use of MSCs from different sources for the treatment of T1D, including the use of allogeneic MSCs derived from adipose tissue (NCT02940418 and NCT02138331).

To date, the use of immunoregulatory MSCs is a very promising topic in the T1D stem cells field. The combination of MSCs with other immunotherapies would offer a novel strategy for the treatment of T1D patients.

\section{Novel Strategies}

\subsection{CAR-T-Cell Therapy}

\subsubsection{Introduction}

In the recent years, an immunotherapy using engineered T-cells expressing chimeric antigen receptors (CARs) specific against CD19 emerged as a major breakthrough in cancer therapy of CD19+ B-cell leukemia [99]. CARs are complex molecules composed of several components, the most common being: (1) An antigen-specific recognition domain, usually a single chain variable region ( $\mathrm{scFv}$ ) from a monoclonal antibody; (2) a hinge region, based on the Fc portion of human immunoglobulin (IgG1 or IgG4), or originating from the hinge domains of CD8a or CD28; (3) a transmembrane domain; and (4) an intracellular tyrosine-based signaling domain [100]. The signaling domain is the engine of the receptor. Its most common component is the intracellular portion of $\mathrm{CD} 3 \zeta$, which is the main signaling chain of CD3 T-cell receptor (TCR) complex. The biggest advantage of CAR-T-cells is that the receptor's interaction with its antigen is independent from major histocompatibility complex (MHC) but it still activates the same TCR's and costimulatory intracellular signaling cascades necessary for T cell activation and expansion.

\subsubsection{CAR-T-Cells and T1D}

Based on the studies with CARs in cancer and increased interest of $\mathrm{T}_{\text {regs }}$ as a potential tool for T1D therapy (see Section 2.3). It is only logical to hypothesize that armoring $T_{\text {regs }}$ with $\beta$ cell-specific CARs would improve $T_{\text {regs' }}$ migration into the pancreas and pancreatic lymph node, thus protecting islet cells from autoimmune destruction. A number of recent studies suggests that there is big potential for CAR- $\mathrm{T}_{\text {regs }}$ therapy in multiple autoimmune or allograft rejection model systems [101-106]. Fransson and colleagues described an interesting approach for $C A R-T_{\text {regs }}$ use in the EAE mouse model [105]. In their study, $\mathrm{CD}^{+} \mathrm{T}$-cells were engineered to express both a CAR specific against myelin oligodendrocyte glycoprotein $\left(\mathrm{MOG}_{35-55}\right)$ and a murine Foxp3 gene to drive $\mathrm{T}_{\text {reg }}$ differentiation, separated by a $2 \mathrm{~A}$ peptide sequence. Intranasal administration of $C A R-\mathrm{T}_{\text {regs }}$ resulted in a successful delivery to the CNS, an efficient suppression of the ongoing inflammation and complete recovery from disease symptoms. Other studies propose the use of CAR- $\mathrm{T}_{\text {regs }}$ in transplant rejection by generating HLA-A2-specific CAR- $\mathrm{T}_{\text {regs }}$ that were isolated from the host [102,104]. These HLA-A2-CAR- $\mathrm{T}_{\text {regs }}$ retained high expression of Foxp3, LAP, GARP, and CTLA-4, and maintained their suppression function in vitro without a significant cytolytic activity. Even though there is still necessity to confirm the stability of $\mathrm{T}_{\text {reg }}$ phenotype, purity, and long term survival after the transfer, this approach is very promising for treating and prevention of transplant rejection by inducing graft-specific tolerance.

CAR- $\mathrm{T}_{\text {regs }}$ were also studied in Hemophilia A, where genetic mutations in F8 gene result in either reduced levels or altered functionality of the blood-clotting protein, Factor VIII (FVIII). In patients with severe hemophilia (no circulating FVIII can be detected), there is a high probability for developing adverse immune reactions to the exogenously administered FVIII protein. Remarkably, administering FVIII-specific human CAR- $\mathrm{T}_{\text {regs }}$ suppressed antibody production in vitro and in vivo in a mouse hemophilia A model. However since FVIII is a soluble protein, the mechanism of this suppression is not entirely clear [101,107]. 
Hansen's group study was an additional proof of concept that $C A R-T_{\text {regs }}$ are a prospective therapy strategy for multiple autoimmune conditions [106]. The authors generated CAR against carcinoembryonic antigen (CEA), a glycoprotein presented on lung adenoepithelia, and then adoptively transferred $\mathrm{T}_{\text {regs }}$ expressing this construct in an experimentally induced allergic asthma mouse model. The CAR- $\mathrm{T}_{\text {regs }}$ accumulated in the lungs and nearby lymph nodes, reducing airway hyper-reactivity, inflammation, mucus production, and eosinophilia.

\subsubsection{Challenges}

Despite the great potential of CAR- $\mathrm{T}_{\text {regs }}$ therapies, there is still no clear strategy on how to use this exciting technology for the treatment of T1D. The biggest challenge is the lack of $\beta$ cell-specific antibodies that can be harnessed to generate islet-protective $C A R-T_{\text {regs. }}$. One possible approach to overcome this problem is to use human islet-specific TCR gene transfer to polyclonal human $\mathrm{T}_{\text {regs. }}$. A recent study where polyclonal $\mathrm{T}_{\text {regs }}$ were transduced with TCR chains derived from two human islet-specific $\mathrm{CD}^{+}$clones showed an improved antigen-specific suppression of these cells and increased potency when compared to polyclonal $T_{\text {regs }}$ [108]. However, such islet-specific $T_{\text {regs }}$ were less responsive to their cognate antigen in comparison to T-cells expressing virus-specific TCRs suggesting that further optimization and/or identifying better TCR clones is still needed.

A new study demonstrated that insulin-specific CAR- $T_{\text {regs }}$ were functional, suppressive and surviving in vivo even though they were not able to prevent spontaneous diabetes in NOD mice [109]. This is not a surprise considering the fact that insulin is a soluble antigen that is present throughout the body and its concentrations fluctuate. Moreover, such a strategy would not be very efficient in patients with T1D where endogenous insulin levels are very low and the daily insulin injections would disturb the normal insulin concentration gradient that might drive the insulin-specific CAR- $T_{\text {regs }}$ into the pancreas.

Therefore, the discovery and study of new $\beta$ cell-specific molecules that could provide proper targeting of CAR- $\mathrm{T}_{\text {reg }} \mathrm{s}$ is needed. While there are some promising molecules such as DPP6 [110]), FXYD2 $\gamma$ a [111], and NTPDase3 [112], all of those would require additional studies confirming their specificity, as well as isolating appropriate monoclonal antibodies that would recognize human $\beta$ cells in vivo before developing a CAR construct for T1D therapy.

\subsubsection{Summary}

In summary, despite the advances in the field of CAR- $\mathrm{T}_{\text {regs }}$ therapies and their great potential to be applied for autoimmune disorders, there is still a lack of an efficient system as well as of appropriate surface $\beta$ cell-specific markers that would allow the generation of effective auto Ag-specific $\mathrm{T}_{\text {regs }}$ that could be used for cell-based therapies in T1D.

\subsection{Microbiota Modulation}

\subsubsection{Introduction}

The microbiota refers to a complex ecosystem of bacteria and viruses, among other microorganisms that inhabits our body, especially the digestive tract. This community greatly exceeds the amount of eukaryotic cells that form the human body and their collective genome, named microbiome, is considerably larger than the human genome. On account of the mutualistic relationship between the host and its gut microbes, the imbalance of the latter, which is termed dysbiosis [113], could spoil gut microbiota (GM) physiological properties leading to harmful effects to the human host [114].

Among the GM properties, there are important metabolic benefits such as improving the digestive functions. Bacteria allow the complete digestion of some food nutrients such as fibers which otherwise cannot be metabolized by eukaryotic cells [115], and participate in the synthesis of some micronutrients [116]. Importantly, some relevant functions have been described for metabolic end products of microbial fermentation. For example, during metabolism of fibers, short-chain fatty 
acids (SCFA) such as butyrate, propionate, and acetate are produced [117]. The former is of great importance and acts as an energy source for colonic epithelial cells, thus contributing to the proper barrier function $[118,119]$. Besides its nutritional impact, the current evidence supports the fundamental role of the GM in the host defense. The intestine works as a boundary that separates the inner and the outer environment and the coexistence of microbial and somatic cells is highly mediated by the epithelial cells (EC). This complex system was well illustrated by Vaishnava et al. who emphasized the interplay between EC and gut microbes and its significance for their proper coexistence [120].

The mechanisms underlying the cross-talk between the gut microbial community and the immune system (IS) are well stablished and it has now became clear the relevance of such interplay in the harmonious balance between the host and its microbiota [114]. The mucosal IS, which is distributed among the different levels of the mucosa layer, has to procure the right equilibrium between tolerance and reactivity, and T-cells are decisive for such balance [121]. Distinct T-cell sub-populations dominate in different gut locations, conditioning the immune activation through complex signaling pathways (28). Because of the impact of both commensal and pathogenic bacteria on the maturation of the IS, the study of the microbiota and gut integrity may clarify the field.

Today there is clear evidence of the relevance of an adequate development of the microbiota and immunity for the host wellness. Data from experimental studies on in vivo models have provided valuable knowledge. Findings from germ-free animal studies revealed important phenotypic and functional characteristics mediated by the intestinal microbes, and emphasized the importance of the microorganisms in the correct development of the human body structures [122]. Certainly, studies on the transfer of microbiota from humans or animal models to animals with known microbiota (gnotobiotic models) are prevalent and they demonstrate that some phenotypic characteristics are dependent on the microbiota [123].

\subsubsection{Microbiota and T1D}

Vaarala et al. elegantly described the three main elements that may explain the connections between an altered intestinal track and T1D [124]. This triad includes a compromised gut permeability, immune dysregulation, and a dysbiotic microbial ecosystem. Additionally to the defective barrier function and intestinal environment, confirmed in later studies in T1D subjects [125], the microbes play a key role also in the development of T1D. For example, the number of anti-islet cell autoantibodies has been shown to correlate with some bacteria genera, suggesting that alterations in the microbiota composition may precede the pathology. Indeed some degree of gut dysbiosis has been observed in prediabetic subjects prior to T1D onset [126].

There is accumulating evidence of the role of GM in diabetic pathology. In fact, a divergent profile of intestinal bacteria has been reported in T1D individuals in comparison to non-diabetic subjects. A case-control study with a total sample of eight children, four cases and four controls, revealed that T1D patients possess distinctly different gut microbiota, compared to healthy subjects, characterized by an increased Bacteroidetes/Firmicutes ratio [127]. The same finding was reported in a later study on Chinese T1D subjects [128]. Giongo et al. emphasized that changes at phyla levels were essentially a result of shifts in specific genera; Clostridiales and Bacteroides in Firmicutes and Bacteroidetes, respectively. They also found a list of bacteria genera predominant in the diabetic and control children [127]. In a related publication, the same research group provided further findings regarding the GM composition in the same sample [129]. It should be noted the increased abundance of advantageous bacteria such as butyrate producing bacteria (BPBs) and mucin-degrading bacteria in healthy controls [129]. The former bacteria group is known to enhance the barrier function through the maintenance of the mucus layer as mentioned above. The later contributes with a better permeability by means of mucin production, aiding in a steady mucus layer as well as gut integrity [130]. A compromised presence of BPBs and the consequent decay of the barrier function is thought to be a primary trigger of pro-diabetic intestinal profile. Akkermansia genus, specifically A. muciniphila is probably, along with the Faecalibacterium genus, the most studied BPB. This taxa is specifically associated 
with the mucus layer by participating in its regulation through mucin degradation and human studies showed an association of its depletion with compromised mucus integrity [131]. Besides its structural role, A. muciniphila may have an effect in the defense response and in vivo studies demonstrated a function in the immune regulation by the activation of immune cells [132]. Indeed, children with T1D presented an under-abundance of A. muciniphila compared to controls [130], in concordance with the compromised microbial butyrate production observed in the NOD mice [133]. The restoration of $A$. muciniphila representation in type 2 diabetic mice also triggered important phenotypic features along with improvements in the barrier function [132]. These findings suggested that A. muciniphila could be a key player in the prevention and management of aberrant microbiota associated with T1D and related autoimmune diseases.

Likewise, microbial diversity appears to be impaired in T1D. A study using samples from eight Finish children in which four case children later developed T1D and the other four were controls, revealed that the case children's samples had an unsatisfactory development in GM diversity, which did not become as complex as controls' and was more heterogeneous among cases [127]. The same finding was reported by Kostic et al. [134]. Giongo et al. emphasized the importance of a compromised phylogenetic diversity in the risk of developing autoimmune diabetes and set the basis of potential screening criteria. Additionally, some functional attributes of the microbiome has also been reviewed in relation to T1D. Brown's team went further and detailed functional differences between controls and cases [129], revealing a greater taxonomic complexity in the control group. Conversely, a reduced metabolic capacity found in cases was associated with lower microbial diversity and predominance of unwanted bacteria taxa such as those matched to a pro-inflammatory state [127,134].

Long cohort studies and randomized controlled trials such as FINDIA (Finnish Dietary Intervention Trial for the Prevention of Type 1 Diabetes), BABYDIET (in German infants), TRIGR (Trial to Reduce IDDM in the Genetically at Risk) and TEDDY among others, offer valuable information regarding the natural history of T1D and the role of GM (reviewed in [123]). Within the findings, the effect of geographical location on intestinal microbiota has received considerable attention. Other in vivo studies have contributed with valuable knowledge as well. For instance, Kriegel and colleagues correlated the abundance of intestinal segmented filamentous bacteria (SFBs) with the development and progression of diabetes in NOD mice [135]. Although a protective role for SFBs could not be presumed, they concluded that SFBs somehow attenuates the progression of T1D and promotes a boost in some T helper cell sub-populations. SFBs were initially considered latent but the current evidence clues that they have a role in mucosal immunity and immune response.

The features and characteristics of a pathogenic T1D-prone microbiome seems to precede the disease, which offers a possibility to anticipate and prevent or delay T1D onset $[118,123,134]$. Therefore, the GM could be used as a potential marker for disease progression. For instance, some specific bacteria taxa, such as the Ruminococcaceae family, have proven to have an inverse relationship with the levels of serum hemoglobin A1c [128], a widely used biomarker for the evaluation of diabetes progression.

A large number of experimental and observational studies demonstrated the efficiency of both probiotic and prebiotics, as well as synbiotics and fermented products, in conferring benefits on the host [136]. Thought probiotic efficiency is specie-dependent, and some methodological and technical issues such as the dose or the capacity to colonize the gastrointestinal track may limit their efficiency [137], this approach seems promising for T1D. Along with the aforementioned dietary modulations, fecal transplants also offer a possibility of changing host's microbiota. The fecal microbiota transplantations (FMTs) were initially used in experimental studies [138] but has proven to be effective in the management of some intestinal pathologies [139] and its use in T1D has been discussed [140]. Despite the controversy about its use, FMTs may be a useful tool for immunomodulation and seems to be a promising approach for the GM modulation.

Some novel publications discuss the relevance of the aforementioned products for T1D management [141,142]. Interestingly, studies in mice models [143] and humans [144] reported beneficial 
outcomes after intervention with potentially beneficial bacteria. For instance, the administration of the probiotic A. muciniphila showed an improved insulin sensitivity and glucose homeostasis, healthier lipid profile, and a pro-inflammatory tone among others changes. Interventions that aimed to promote A. muciniphila abundance through a prebiotic effect $[144,145]$ offered positive effects as well.

\subsubsection{Summary}

The above reported findings provide convincing evidence that the GM should not be dismissed on the management of T1D. Available information, especially prospective human studies, seems to suggest a main role of the GM in the risk and development of autoimmune disorders. Efforts to identify specific targets in the GM would help to improve the effectiveness of these novel approaches and provide diabetic patients with alternative medical treatments.

\subsection{JAK Pathway Inhibition}

\subsubsection{Introduction}

The mammalian Janus kinase (JAK) family contains three JAKs (JAK1, 2, 3) and tyrosine kinase 2 (TYK2), which selectively bind different receptor chains [146]. Upon binding of ligand to its cognate receptor, associated JAKs become activated and undergo phosphorylation, which creates docking sites for the SH2 domain of the cytoplasmic transcription factors termed signal transducers and activators of transcription (STATs). The human STAT family contains seven STATs: STAT1, STAT2, STAT3, STAT4, STAT5A, STAT5B, and STAT6. Following phosphorylation, STATs are translocated to the nucleus, dimerize, and bind to specific DNA sequences to regulate gene transcription [147]. The JAK-STAT pathway plays a pivotal role for the downstream signaling of inflammatory cytokines, such as IFNs, ILs, and growth factors [148].

\subsubsection{JAKs and T1D}

A type I IFN signature precedes the detection of autoantibodies in children genetically at risk for T1D [149] and IFN $\alpha$ is expressed in human islets from type 1 diabetic patients [150,151]. MHC class I overexpression is induced by IFN $\alpha$ [152] and IFN $\gamma$ [153] in human islets from T1D patients and IFN $\alpha$ also induces $\beta$ cell endoplasmic reticulum stress and chemokine production [154].

Receptor engagement by IFN $\alpha$ triggers JAK1-TYK2 heterodimer signaling (Figure 2). TYK2 has been associated with several autoimmune diseases including rheumatoid arthritis and T1D [155,156]. Six TYK2 single nucleotide polymorphisms (SNPs) (rs34536443, rs2304256, rs280523, rs280519, rs12720270, and rs12720356) have been explored in relation to autoimmunity. Crucially, the SNP rs2304256 causes a missense mutation in TYK2, and has been associated with protection against T1D [155]. 


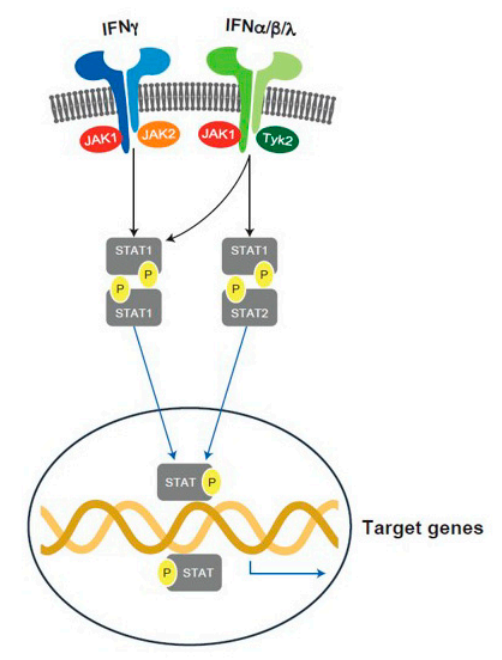

Figure 2. JAK1-TYK2 heterodimer signaling pathway.

Downstream IFN $\alpha /$ IFN $\gamma$ signaling is STAT1 dependent (Figure 1), and STAT1 is overexpressed in T1D islets and strongly correlates with HLA class I expression in $\beta$ cells [153].

IFN $\gamma$ is also involved in the expression of the CXCL10, which seems to be activated in islets from both T1D patients [157] and non-obese diabetic (NOD) mice $[157,158]$. CXCL10 promotes pathogenic T-cell infiltration into the pancreatic islets leading to $\beta$ cell apoptosis and its neutralization prevents diabetes in NOD mice [159]. A lack of IFN- $\gamma$ delays the progress of autoimmune diabetes in NOD mice [160].

Recent evidence further supports the rationale that IFN-driven JAK-STAT pathway activation significantly contributes to T1D pathogenesis. Patients with STAT3 gain-of-function germline mutations are susceptible to T1D with the median age of onset being 8 weeks. Furthermore, approximately $15 \%$ of patients treated with immune checkpoint inhibitors develop endocrine autoimmunity [161], including pancreatic $\beta$ cell targeting [162], leading to T1D [163]. Consistent with these observations, inhibition of PD-1-PDL1 signaling accelerates diabetes in NOD mice [164].

Prior treatment of in vitro human islets with ruxolitinib (JAK1/2) significantly reduced IFN $\alpha$ mediated inflammatory and ER stress markers [165]. Moreover, treatment of NOD mice with a JAK1/JAK2 inhibitor (AZD1480) blocked MHC class I upregulation on $\beta$ cells and reversed autoimmune insulitis by reducing immune cell infiltration into islets in newly diagnosed animals [166].

Finally, pancreas-specific genetic knockout studies revealed an essential role for STAT3 in islet architecture, but it is dispensable for the function of mature islet $[167,168]$. In contrast, STAT5 is only important for age-dependent glucose intolerance [169]. These studies suggest that $\beta$ cell function is minimally impacted by JAK-STAT pathway inhibition.

\subsubsection{Summary}

Taken together, IFN driven T1D pathogenesis can be potentially downregulated by inhibiting the downstream JAK-STAT pathway.

\section{Concluding Remarks and Outlook}

Diabetes is a complex disease that originates from dysfunction and destruction of beta cells as a result of a pathogenic response that involves both the adaptive and innate immune system $[170,171]$. During T1D development, T-cells seem to play a crucial role for destruction of beta cells [172]. Therefore, T-cells have been target of most immunotherapy strategies, dues to the main hypothesis that beta cells could survive by suppressing the pathogenic reactivity of specific T-cells. Although these strategies have demonstrated to be effective, unfortunately, the efficacy was short-lived. On the other hand, immunotherapy protocols based on specific antigens, such as vaccination with peptides 
derived from beta cells, should take into account the high degree of diversity in the response of specific T-cells against beta cells among individuals with T1D [173]. For this reason, the most effective approach should contemplate the combination of different strategies in order to allow the elimination of islet-infiltrating $T$ effector cells through different mechanism. In this sense, new strategies with the objective of improving glycemic control are constantly investigated with the goal to address the long-term insulin dependence that leads to a poor quality of life.

In addition to immune interventions, other ongoing studies are investigating ways to restore insulin secretion using different approaches. It is important to note that, due to the heterogeneity of T1D, the future of T1D treatment strategies most probably would be in direction of a more personalized approach.

Funding: Miriam Cabello-Olmo was granted by the Industrial PhD program (Navarre Government) (Ref 001114082016000011).

Acknowledgments: The authors would like to thank Mohini Huarte for helping in the English edition of the final version of the manuscript.

Conflicts of Interest: P.S. and E.H. are employees and shareholders of Incyte Corporation. M.C.-O., M.A., I.R. and M.B. have no conflict of interest.

\section{References}

1. Patterson, C.; Guariguata, L.; Dahlquist, G.; Soltesz, G.; Ogle, G.; Silink, M. Diabetes in the young-A global view and worldwide estimates of numbers of children with type 1 diabetes. Diabetes Res. Clin. Pract. 2014, 103, 161-175. [CrossRef] [PubMed]

2. Maahs, D.M.; West, N.A.; Lawrence, J.M.; Mayer-Davis, E.J. Epidemiology of type 1 diabetes. Endocrinol. Metab. Clin. N. Am. 2010, 39, 481-497. [CrossRef] [PubMed]

3. Barrett, J.C.; Clayton, D.G.; Concannon, P.; Akolkar, B.; Cooper, J.D.; Erlich, H.A.; Julier, C.; Morahan, G.; Nerup, J.; Nierras, C.; et al. Genome-wide association study and meta-analysis find that over 40 loci affect risk of type 1 diabetes. Nat. Genet. 2009, 41, 703-707. [CrossRef] [PubMed]

4. Pociot, F.; Akolkar, B.; Concannon, P.; Erlich, H.A.; Julier, C.; Morahan, G.; Nierras, C.R.; Todd, J.A.; Rich, S.S.; Nerup, J. Genetics of type 1 diabetes: What's next? Diabetes 2010, 59, 1561-1571. [CrossRef] [PubMed]

5. Nerup, J.; Platz, P.; Andersen, O.O.; Christy, M.; Lyngsoe, J.; Poulsen, J.E.; Ryder, L.P.; Nielsen, L.S.; Thomsen, M.; Svejgaard, A. HL-A antigens and diabetes mellitus. Lancet 1974, 2, 864-866. [CrossRef]

6. Clark, M.; Kroger, C.J.; Tisch, R.M. Type 1 Diabetes: A Chronic Anti-Self-Inflammatory Response. Front. Immunol. 2017, 8, 1898. [CrossRef] [PubMed]

7. Shapiro, A.M.; Ricordi, C.; Hering, B.J.; Auchincloss, H.; Lindblad, R.; Robertson, R.P.; Secchi, A.; Brendel, M.D.; Berney, T.; Brennan, D.C.; et al. International trial of the Edmonton protocol for islet transplantation. N. Engl. J. Med. 2006, 355, 1318-1330. [CrossRef]

8. Perseghin, G.; Fiorina, P.; De Cobelli, F.; Scifo, P.; Esposito, A.; Canu, T.; Danna, M.; Gremizzi, C.; Secchi, A.; Luzi, L.; et al. Cross-sectional assessment of the effect of kidney and kidney-pancreas transplantation on resting left ventricular energy metabolism in type 1 diabetic-uremic patients: A phosphorous-31 magnetic resonance spectroscopy study. J. Am. Coll. Cardiol. 2005, 46, 1085-1092. [CrossRef]

9. Simmons, K.M.; Michels, A.W. Type 1 diabetes: A predictable disease. World J. Diabetes 2015, 6, 380-390. [CrossRef]

10. Regnell, S.E.; Lernmark, A. Early prediction of autoimmune (type 1) diabetes. Diabetologia 2017, 60, $1370-1381$. [CrossRef]

11. Di Lorenzo, T.P.; Peakman, M.; Roep, B.O. Translational mini-review series on type 1 diabetes: Systematic analysis of T cell epitopes in autoimmune diabetes. Clin. Exp. Immunol. 2007, 148, 1-16. [CrossRef] [PubMed]

12. Wherrett, D.K.; Chiang, J.L.; Delamater, A.M.; DiMeglio, L.A.; Gitelman, S.E.; Gottlieb, P.A.; Herold, K.C.; Lovell, D.J.; Orchard, T.J.; Ryan, C.M.; et al. Defining pathways for development of disease-modifying therapies in children with type 1 diabetes: A consensus report. Diabetes Care 2015, 38, 1975-1985. [CrossRef] [PubMed] 
13. Parikka, V.; Nanto-Salonen, K.; Saarinen, M.; Simell, T.; Ilonen, J.; Hyoty, H.; Veijola, R.; Knip, M.; Simell, O. Early seroconversion and rapidly increasing autoantibody concentrations predict prepubertal manifestation of type 1 diabetes in children at genetic risk. Diabetologia 2012, 55, 1926-1936. [CrossRef]

14. Krischer, J.P.; Lynch, K.F.; Schatz, D.A.; Ilonen, J.; Lernmark, A.; Hagopian, W.A.; Rewers, M.J.; She, J.X.; Simell, O.G.; Toppari, J.; et al. The 6 year incidence of diabetes-associated autoantibodies in genetically at-risk children: The TEDDY study. Diabetologia 2015, 58, 980-987. [CrossRef] [PubMed]

15. Bosi, E.; Boulware, D.C.; Becker, D.J.; Buckner, J.H.; Geyer, S.; Gottlieb, P.A.; Henderson, C.; Kinderman, A.; Sosenko, J.M.; Steck, A.K.; et al. Impact of Age and Antibody Type on Progression From Single to Multiple Autoantibodies in Type 1 Diabetes Relatives. J. Clin. Endocrinol. Metab. 2017, 102, 2881-2886. [CrossRef]

16. American Diabetes Association. 2. Classification and Diagnosis of Diabetes: Standards of Medical Care in Diabetes-2019. Diabetes Care 2019, 42, S13-S28. [CrossRef]

17. Herold, K.C.; Gitelman, S.E.; Ehlers, M.R.; Gottlieb, P.A.; Greenbaum, C.J.; Hagopian, W.; Boyle, K.D.; Keyes-Elstein, L.; Aggarwal, S.; Phippard, D.; et al. Teplizumab (anti-CD3 mAb) treatment preserves C-peptide responses in patients with new-onset type 1 diabetes in a randomized controlled trial: Metabolic and immunologic features at baseline identify a subgroup of responders. Diabetes 2013, 62, 3766-3774. [CrossRef]

18. Rigby, M.R.; DiMeglio, L.A.; Rendell, M.S.; Felner, E.I.; Dostou, J.M.; Gitelman, S.E.; Patel, C.M.; Griffin, K.J.; Tsalikian, E.; Gottlieb, P.A.; et al. Targeting of memory T cells with alefacept in new-onset type 1 diabetes (T1DAL study): 12 Month results of a randomised, double-blind, placebo-controlled phase 2 trial. Lancet Diabetes Endocrinol. 2013, 1, 284-294. [CrossRef]

19. Mahon, J.L.; Sosenko, J.M.; Rafkin-Mervis, L.; Krause-Steinrauf, H.; Lachin, J.M.; Thompson, C.; Bingley, P.J.; Bonifacio, E.; Palmer, J.P.; Eisenbarth, G.S.; et al. The TrialNet Natural History Study of the Development of Type 1 Diabetes: Objectives, design, and initial results. Pediatr. Diabetes 2009, 10, 97-104. [CrossRef]

20. Zhao, Z.; Miao, D.; Michels, A.; Steck, A.; Dong, F.; Rewers, M.; Yu, L. A multiplex assay combining insulin, GAD, IA-2 and transglutaminase autoantibodies to facilitate screening for pre-type 1 diabetes and celiac disease. J. Immunol. Methods 2016, 430, 28-32. [CrossRef]

21. Slim, I.B. Cardiovascular risk in type 1 diabetes mellitus. Indian J. Endocrinol. Metab. 2013, 17, S7-S13. [CrossRef] [PubMed]

22. Makino, S.; Kunimoto, K.; Muraoka, Y.; Mizushima, Y.; Katagiri, K.; Tochino, Y. Breeding of a non-obese, diabetic strain of mice. Jikken Dobutsu 1980, 29, 1-13. [PubMed]

23. Nakhooda, A.F.; Like, A.A.; Chappel, C.I.; Murray, F.T.; Marliss, E.B. The spontaneously diabetic Wistar rat: Metabolic and morphologic studies. Diabetes 1977, 26, 100-112. [CrossRef]

24. Jackson, R.; Rassi, N.; Crump, T.; Haynes, B.; Eisenbarth, G.S. The BB diabetic rat: Profound T-cell lymphocytopenia. Diabetes 1981, 30, 887-889. [CrossRef] [PubMed]

25. Matsumoto, M.; Yagi, H.; Kunimoto, K.; Kawaguchi, J.; Makino, S.; Harada, M. Transfer of autoimmune diabetes from diabetic NOD mice to NOD athymic nude mice: The roles of $\mathrm{T}$ cell subsets in the pathogenesis. Cell. Immunol. 1993, 148, 189-197. [CrossRef] [PubMed]

26. Yagi, H.; Matsumoto, M.; Kunimoto, K.; Kawaguchi, J.; Makino, S.; Harada, M. Analysis of the roles of CD4+ and CD8+ T cells in autoimmune diabetes of NOD mice using transfer to NOD athymic nude mice. Eur. J. Immunol. 1992, 22, 2387-2393. [CrossRef] [PubMed]

27. Pontesilli, O.; Carotenuto, P.; Gazda, L.S.; Pratt, P.F.; Prowse, S.J. Circulating lymphocyte populations and autoantibodies in non-obese diabetic (NOD) mice: A longitudinal study. Clin. Exp. Immunol. 1987, 70, 84-93. [PubMed]

28. Shoda, L.K.; Young, D.L.; Ramanujan, S.; Whiting, C.C.; Atkinson, M.A.; Bluestone, J.A.; Eisenbarth, G.S.; Mathis, D.; Rossini, A.A.; Campbell, S.E.; et al. A comprehensive review of interventions in the NOD mouse and implications for translation. Immunity 2005, 23, 115-126. [CrossRef]

29. Pow Sang, L.; Majji, S.; Casares, S.; Brumeanu, T.D. Long-term silencing of autoimmune diabetes and improved life expectancy by a soluble pHLA-DR4 chimera in a newly-humanized NOD/DR4/B7 mouse. Hum. Vaccines Immunother. 2014, 10, 693-699. [CrossRef]

30. Wen, L.; Ley, R.E.; Volchkov, P.Y.; Stranges, P.B.; Avanesyan, L.; Stonebraker, A.C.; Hu, C.; Wong, F.S.; Szot, G.L.; Bluestone, J.A.; et al. Innate immunity and intestinal microbiota in the development of Type 1 diabetes. Nature 2008, 455, 1109-1113. [CrossRef] 
31. Hansen, C.H.; Krych, L.; Nielsen, D.S.; Vogensen, F.K.; Hansen, L.H.; Sorensen, S.J.; Buschard, K.; Hansen, A.K. Early life treatment with vancomycin propagates Akkermansia muciniphila and reduces diabetes incidence in the NOD mouse. Diabetologia 2012, 55, 2285-2294. [CrossRef] [PubMed]

32. Peng, J.; Narasimhan, S.; Marchesi, J.R.; Benson, A.; Wong, F.S.; Wen, L. Long term effect of gut microbiota transfer on diabetes development. J. Autoimmun. 2014, 53, 85-94. [CrossRef] [PubMed]

33. Wesley, J.D.; Sather, B.D.; Perdue, N.R.; Ziegler, S.F.; Campbell, D.J. Cellular requirements for diabetes induction in DO11.10xRIPmOVA mice. J. Immunol. 2010, 185, 4760-4768. [CrossRef] [PubMed]

34. Nagy, N.; Kaber, G.; Johnson, P.Y.; Gebe, J.A.; Preisinger, A.; Falk, B.A.; Sunkari, V.G.; Gooden, M.D.; Vernon, R.B.; Bogdani, M.; et al. Inhibition of hyaluronan synthesis restores immune tolerance during autoimmune insulitis. J. Clin. Investig. 2015, 125, 3928-3940. [CrossRef] [PubMed]

35. Makhlouf, L.; Grey, S.T.; Dong, V.; Csizmadia, E.; Arvelo, M.B.; Auchincloss, H., Jr.; Ferran, C.; Sayegh, M.H. Depleting anti-CD4 monoclonal antibody cures new-onset diabetes, prevents recurrent autoimmune diabetes, and delays allograft rejection in nonobese diabetic mice. Transplantation 2004, 77, 990-997. [CrossRef]

36. Cameron, M.J.; Arreaza, G.A.; Waldhauser, L.; Gauldie, J.; Delovitch, T.L. Immunotherapy of spontaneous type 1 diabetes in nonobese diabetic mice by systemic interleukin- 4 treatment employing adenovirus vector-mediated gene transfer. Gene Ther. 2000, 7, 1840-1846. [CrossRef]

37. Feili-Hariri, M.; Falkner, D.H.; Gambotto, A.; Papworth, G.D.; Watkins, S.C.; Robbins, P.D.; Morel, P.A. Dendritic cells transduced to express interleukin-4 prevent diabetes in nonobese diabetic mice with advanced insulitis. Hum. Gene Ther. 2003, 14, 13-23. [CrossRef]

38. Clemente-Casares, X.; Tsai, S.; Huang, C.; Santamaria, P. Antigen-specific therapeutic approaches in Type 1 diabetes. Cold Spring Harb. Perspect. Med. 2012, 2, a007773. [CrossRef]

39. Miller, S.D.; Turley, D.M.; Podojil, J.R. Antigen-specific tolerance strategies for the prevention and treatment of autoimmune disease. Nat. Rev. Immunol. 2007, 7, 665-677. [CrossRef]

40. Bone, R.N.; Evans-Molina, C. Combination Immunotherapy for Type 1 Diabetes. Curr. Diabetes Rep. 2017, 17, 50. [CrossRef]

41. Orban, T.; Bundy, B.; Becker, D.J.; DiMeglio, L.A.; Gitelman, S.E.; Goland, R.; Gottlieb, P.A.; Greenbaum, C.J.; Marks, J.B.; Monzavi, R.; et al. Co-stimulation modulation with abatacept in patients with recent-onset type 1 diabetes: A randomised, double-blind, placebo-controlled trial. Lancet 2011, 378, 412-419. [CrossRef]

42. Herold, K.C.; Hagopian, W.; Auger, J.A.; Poumian-Ruiz, E.; Taylor, L.; Donaldson, D.; Gitelman, S.E.; Harlan, D.M.; Xu, D.; Zivin, R.A.; et al. Anti-CD3 monoclonal antibody in new-onset type 1 diabetes mellitus. N. Engl. J. Med. 2002, 346, 1692-1698. [CrossRef] [PubMed]

43. Haller, M.J.; Gitelman, S.E.; Gottlieb, P.A.; Michels, A.W.; Rosenthal, S.M.; Shuster, J.J.; Zou, B.; Brusko, T.M.; Hulme, M.A.; Wasserfall, C.H.; et al. Anti-thymocyte globulin/G-CSF treatment preserves beta cell function in patients with established type 1 diabetes. J. Clin. Investig. 2015, 125, 448-455. [CrossRef] [PubMed]

44. Lopes, M.; Kutlu, B.; Miani, M.; Bang-Berthelsen, C.H.; Storling, J.; Pociot, F.; Goodman, N.; Hood, L.; Welsh, N.; Bontempi, G.; et al. Temporal profiling of cytokine-induced genes in pancreatic beta-cells by meta-analysis and network inference. Genomics 2014, 103, 264-275. [CrossRef] [PubMed]

45. Cabrera, S.M.; Wang, X.; Chen, Y.G.; Jia, S.; Kaldunski, M.L.; Greenbaum, C.J.; Type 1 Diabetes TrialNet Canakinumab Study Group; Mandrup-Poulsen, T.; Group, A.S.; Hessner, M.J. Interleukin-1 antagonism moderates the inflammatory state associated with Type 1 diabetes during clinical trials conducted at disease onset. Eur. J. Immunol. 2016, 46, 1030-1046. [CrossRef]

46. Den Broeder, A.A.; de Jong, E.; Franssen, M.J.; Jeurissen, M.E.; Flendrie, M.; van den Hoogen, F.H. Observational study on efficacy, safety, and drug survival of anakinra in rheumatoid arthritis patients in clinical practice. Ann. Rheum. Dis. 2006, 65, 760-762. [CrossRef]

47. Mandrup-Poulsen, T.; Pickersgill, L.; Donath, M.Y. Blockade of interleukin 1 in type 1 diabetes mellitus. Nat. Rev. Endocrinol. 2010, 6, 158-166. [CrossRef]

48. Mastrandrea, L.; Yu, J.; Behrens, T.; Buchlis, J.; Albini, C.; Fourtner, S.; Quattrin, T. Etanercept treatment in children with new-onset type 1 diabetes: Pilot randomized, placebo-controlled, double-blind study. Diabetes Care 2009, 32, 1244-1249. [CrossRef]

49. Kuhn, C.; Weiner, H.L. Therapeutic anti-CD3 monoclonal antibodies: From bench to bedside. Immunotherapy 2016, 8, 889-906. [CrossRef] 
50. Pescovitz, M.D.; Greenbaum, C.J.; Krause-Steinrauf, H.; Becker, D.J.; Gitelman, S.E.; Goland, R.; Gottlieb, P.A.; Marks, J.B.; McGee, P.F.; Moran, A.M.; et al. Rituximab, B-lymphocyte depletion, and preservation of beta-cell function. N. Engl. J. Med. 2009, 361, 2143-2152. [CrossRef]

51. Polychronakos, C.; Li, Q. Understanding type 1 diabetes through genetics: Advances and prospects. Nat. Rev. Genet. 2011, 12, 781-792. [CrossRef]

52. Wherrett, D.K.; Bundy, B.; Becker, D.J.; DiMeglio, L.A.; Gitelman, S.E.; Goland, R.; Gottlieb, P.A.; Greenbaum, C.J.; Herold, K.C.; Marks, J.B.; et al. Antigen-based therapy with glutamic acid decarboxylase (GAD) vaccine in patients with recent-onset type 1 diabetes: A randomised double-blind trial. Lancet 2011, 378, 319-327. [CrossRef]

53. Iwasaki, A.; Medzhitov, R. Regulation of adaptive immunity by the innate immune system. Science 2010, 327, $291-295$. [CrossRef] [PubMed]

54. Balamurugan, A.N.; Naziruddin, B.; Lockridge, A.; Tiwari, M.; Loganathan, G.; Takita, M.; Matsumoto, S.; Papas, K.; Trieger, M.; Rainis, H.; et al. Islet product characteristics and factors related to successful human islet transplantation from the Collaborative Islet Transplant Registry (CITR) 1999-2010. Am. J. Transplant. 2014, 14, 2595-2606. [CrossRef]

55. Faradji, R.N.; Tharavanij, T.; Messinger, S.; Froud, T.; Pileggi, A.; Monroy, K.; Mineo, D.; Baidal, D.A.; Cure, P.; Ponte, G.; et al. Long-term insulin independence and improvement in insulin secretion after supplemental islet infusion under exenatide and etanercept. Transplantation 2008, 86, 1658-1665. [CrossRef]

56. Suarez-Pinzon, W.L.; Cembrowski, G.S.; Rabinovitch, A. Combination therapy with a dipeptidyl peptidase-4 inhibitor and a proton pump inhibitor restores normoglycaemia in non-obese diabetic mice. Diabetologia 2009, 52, 1680-1682. [CrossRef]

57. Suarez-Pinzon, W.L.; Rabinovitch, A. Combination therapy with a dipeptidyl peptidase-4 inhibitor and a proton pump inhibitor induces beta-cell neogenesis from adult human pancreatic duct cells implanted in immunodeficient mice. Cell Transplant. 2011, 20, 1343-1349. [CrossRef]

58. Suarez-Pinzon, W.L.; Power, R.F.; Yan, Y.; Wasserfall, C.; Atkinson, M.; Rabinovitch, A. Combination therapy with glucagon-like peptide-1 and gastrin restores normoglycemia in diabetic NOD mice. Diabetes 2008, 57, 3281-3288. [CrossRef]

59. Vigouroux, S.; Yvon, E.; Biagi, E.; Brenner, M.K. Antigen-induced regulatory T cells. Blood 2004, 104, $26-33$. [CrossRef]

60. Griffin, K.J.; Thompson, P.A.; Gottschalk, M.; Kyllo, J.H.; Rabinovitch, A. Combination therapy with sitagliptin and lansoprazole in patients with recent-onset type 1 diabetes (REPAIR-T1D): 12-Month results of a multicentre, randomised, placebo-controlled, phase 2 trial. Lancet Diabetes Endocrinol. 2014, 2, 710-718. [CrossRef]

61. Giannoukakis, N.; Phillips, B.; Finegold, D.; Harnaha, J.; Trucco, M. Phase I (safety) study of autologous tolerogenic dendritic cells in type 1 diabetic patients. Diabetes Care 2011, 34, 2026-2032. [CrossRef]

62. D’Addio, F.; Valderrama Vasquez, A.; Ben Nasr, M.; Franek, E.; Zhu, D.; Li, L.; Ning, G.; Snarski, E.; Fiorina, P. Autologous nonmyeloablative hematopoietic stem cell transplantation in new-onset type 1 diabetes: A multicenter analysis. Diabetes 2014, 63, 3041-3046. [CrossRef]

63. Vital, E.M.; Emery, P. Abatacept in the treatment of rheumatoid arthritis. Ther. Clin. Risk Manag. 2006, 2, 365-375. [CrossRef]

64. Haller, M.J.; Schatz, D.A.; Skyler, J.S.; Krischer, J.P.; Bundy, B.N.; Miller, J.L.; Atkinson, M.A.; Becker, D.J.; Baidal, D.; DiMeglio, L.A.; et al. Low-Dose Anti-Thymocyte Globulin (ATG) Preserves beta-Cell Function and Improves HbA1c in New-Onset Type 1 Diabetes. Diabetes Care 2018, 41, 1917-1925. [CrossRef]

65. Nepom, G.T.; Ehlers, M.; Mandrup-Poulsen, T. Anti-cytokine therapies in T1D: Concepts and strategies. Clin. Immunol. 2013, 149, 279-285. [CrossRef]

66. Sumpter, K.M.; Adhikari, S.; Grishman, E.K.; White, P.C. Preliminary studies related to anti-interleukin-1beta therapy in children with newly diagnosed type 1 diabetes. Pediatr. Diabetes 2011, 12, 656-667. [CrossRef]

67. Crino, A.; Schiaffini, R.; Manfrini, S.; Mesturino, C.; Visalli, N.; Beretta Anguissola, G.; Suraci, C.; Pitocco, D.; Spera, S.; Corbi, S.; et al. A randomized trial of nicotinamide and vitamin $\mathrm{E}$ in children with recent onset type 1 diabetes (IMDIAB IX). Eur. J. Endocrinol. 2004, 150, 719-724. [CrossRef]

68. Hundhausen, C.; Roth, A.; Whalen, E.; Chen, J.; Schneider, A.; Long, S.A.; Wei, S.; Rawlings, R.; Kinsman, M.; Evanko, S.P.; et al. Enhanced T cell responses to IL-6 in type 1 diabetes are associated with early clinical disease and increased IL-6 receptor expression. Sci. Transl. Med. 2016, 8, 356ra119. [CrossRef] 
69. Tanaka, T.; Narazaki, M.; Kishimoto, T. Interleukin (IL-6) Immunotherapy. Cold Spring Harb. Perspect. Biol. 2018, 10. [CrossRef]

70. Bluestone, J.A.; Buckner, J.H.; Fitch, M.; Gitelman, S.E.; Gupta, S.; Hellerstein, M.K.; Herold, K.C.; Lares, A.; Lee, M.R.; Li, K.; et al. Type 1 diabetes immunotherapy using polyclonal regulatory T cells. Sci. Transl. Med. 2015, 7, 315ra189. [CrossRef]

71. Hartemann, A.; Bensimon, G.; Payan, C.A.; Jacqueminet, S.; Bourron, O.; Nicolas, N.; Fonfrede, M.; Rosenzwajg, M.; Bernard, C.; Klatzmann, D. Low-dose interleukin 2 in patients with type 1 diabetes: A phase 1/2 randomised, double-blind, placebo-controlled trial. Lancet Diabetes Endocrinol. 2013, 1, $295-305$. [CrossRef]

72. Bogdani, M.; Johnson, P.Y.; Potter-Perigo, S.; Nagy, N.; Day, A.J.; Bollyky, P.L.; Wight, T.N. Hyaluronan and hyaluronan-binding proteins accumulate in both human type 1 diabetic islets and lymphoid tissues and associate with inflammatory cells in insulitis. Diabetes 2014, 63, 2727-2743. [CrossRef]

73. Aronson, R.; Gottlieb, P.A.; Christiansen, J.S.; Donner, T.W.; Bosi, E.; Bode, B.W.; Pozzilli, P.; Group, D.I. Low-dose otelixizumab anti-CD3 monoclonal antibody DEFEND-1 study: Results of the randomized phase III study in recent-onset human type 1 diabetes. Diabetes Care 2014, 37, 2746-2754. [CrossRef]

74. Marino, E.; Silveira, P.A.; Stolp, J.; Grey, S.T. B cell-directed therapies in type 1 diabetes. Trends Immunol. 2011, 32, 287-294. [CrossRef]

75. Townsend, M.J.; Monroe, J.G.; Chan, A.C. B-cell targeted therapies in human autoimmune diseases: An updated perspective. Immunol. Rev. 2010, 237, 264-283. [CrossRef]

76. Coppieters, K.; von Herrath, M. Antigen-Specific Peptide Immunotherapy for Type 1 Diabetes: Proof of Safety, Hope for Efficacy. Cell Metab. 2017, 26, 595-597. [CrossRef]

77. Thrower, S.L.; James, L.; Hall, W.; Green, K.M.; Arif, S.; Allen, J.S.; Van-Krinks, C.; Lozanoska-Ochser, B.; Marquesini, L.; Brown, S.; et al. Proinsulin peptide immunotherapy in type 1 diabetes: Report of a first-in-man Phase I safety study. Clin. Exp. Immunol. 2009, 155, 156-165. [CrossRef]

78. Alhadj Ali, M.; Liu, Y.F.; Arif, S.; Tatovic, D.; Shariff, H.; Gibson, V.B.; Yusuf, N.; Baptista, R.; Eichmann, M.; Petrov, N.; et al. Metabolic and immune effects of immunotherapy with proinsulin peptide in human new-onset type 1 diabetes. Sci. Transl. Med. 2017, 9. [CrossRef]

79. Tian, J.; Clare-Salzler, M.; Herschenfeld, A.; Middleton, B.; Newman, D.; Mueller, R.; Arita, S.; Evans, C.; Atkinson, M.A.; Mullen, Y.; et al. Modulating autoimmune responses to GAD inhibits disease progression and prolongs islet graft survival in diabetes-prone mice. Nat. Med. 1996, 2, 1348-1353. [CrossRef]

80. Yu, H.; Paiva, R.; Flavell, R.A. Harnessing the power of regulatory T-cells to control autoimmune diabetes: Overview and perspective. Immunology 2018, 153, 161-170. [CrossRef]

81. Guilliams, M.; Ginhoux, F.; Jakubzick, C.; Naik, S.H.; Onai, N.; Schraml, B.U.; Segura, E.; Tussiwand, R.; Yona, S. Dendritic cells, monocytes and macrophages: A unified nomenclature based on ontogeny. Nat. Rev. Immunol. 2014, 14, 571-578. [CrossRef]

82. Henry, R.A.; Kendall, P.L.; Thomas, J.W. Autoantigen-specific B-cell depletion overcomes failed immune tolerance in type 1 diabetes. Diabetes 2012, 61, 2037-2044. [CrossRef]

83. Gangemi, A.; Salehi, P.; Hatipoglu, B.; Martellotto, J.; Barbaro, B.; Kuechle, J.B.; Qi, M.; Wang, Y.; Pallan, P.; Owens, C.; et al. Islet transplantation for brittle type 1 diabetes: The UIC protocol. Am. J. Transplant. 2008, 8, 1250-1261. [CrossRef]

84. Bell, G.M.; Anderson, A.E.; Diboll, J.; Reece, R.; Eltherington, O.; Harry, R.A.; Fouweather, T.; MacDonald, C.; Chadwick, T.; McColl, E.; et al. Autologous tolerogenic dendritic cells for rheumatoid and inflammatory arthritis. Ann. Rheum. Dis. 2017, 76, 227-234. [CrossRef]

85. Van de Pavert, S.A.; Mebius, R.E. New insights into the development of lymphoid tissues. Nat. Rev. Immunol. 2010, 10, 664-674. [CrossRef]

86. Di Caro, V.; Phillips, B.; Engman, C.; Harnaha, J.; Trucco, M.; Giannoukakis, N. Retinoic acid-producing, ex-vivo-generated human tolerogenic dendritic cells induce the proliferation of immunosuppressive $\mathrm{B}$ lymphocytes. Clin. Exp. Immunol. 2013, 174, 302-317. [CrossRef]

87. Morelli, A.E.; Thomson, A.W. Tolerogenic dendritic cells and the quest for transplant tolerance. Nat. Rev. Immunol. 2007, 7, 610-621. [CrossRef]

88. Voltarelli, J.C.; Couri, C.E.; Stracieri, A.B.; Oliveira, M.C.; Moraes, D.A.; Pieroni, F.; Coutinho, M.; Malmegrim, K.C.; Foss-Freitas, M.C.; Simoes, B.P.; et al. Autologous nonmyeloablative hematopoietic stem cell transplantation in newly diagnosed type 1 diabetes mellitus. JAMA 2007, 297, 1568-1576. [CrossRef] 
89. Snarski, E.; Milczarczyk, A.; Halaburda, K.; Torosian, T.; Paluszewska, M.; Urbanowska, E.; Krol, M.; Boguradzki, P.; Jedynasty, K.; Franek, E.; et al. Immunoablation and autologous hematopoietic stem cell transplantation in the treatment of new-onset type 1 diabetes mellitus: Long-term observations. Bone Marrow Transplant. 2016, 51, 398-402. [CrossRef]

90. Malmegrim, K.C.; de Azevedo, J.T.; Arruda, L.C.; Abreu, J.R.; Couri, C.E.; de Oliveira, G.L.; Palma, P.V.; Scortegagna, G.T.; Stracieri, A.B.; Moraes, D.A.; et al. Immunological Balance Is Associated with Clinical Outcome after Autologous Hematopoietic Stem Cell Transplantation in Type 1 Diabetes. Front. Immunol. 2017, 8, 167. [CrossRef]

91. Murphy, M.B.; Moncivais, K.; Caplan, A.I. Mesenchymal stem cells: Environmentally responsive therapeutics for regenerative medicine. Exp. Mol. Med. 2013, 45, e54. [CrossRef]

92. Bianco, P.; Cao, X.; Frenette, P.S.; Mao, J.J.; Robey, P.G.; Simmons, P.J.; Wang, C.Y. The meaning, the sense and the significance: Translating the science of mesenchymal stem cells into medicine. Nat. Med. 2013, 19, 35-42. [CrossRef]

93. Eckert, M.A.; Vu, Q.; Xie, K.; Yu, J.; Liao, W.; Cramer, S.C.; Zhao, W. Evidence for high translational potential of mesenchymal stromal cell therapy to improve recovery from ischemic stroke. J. Cereb. Blood Flow Metab. 2013, 33, 1322-1334. [CrossRef]

94. Wang, Y.; Chen, X.; Cao, W.; Shi, Y. Plasticity of mesenchymal stem cells in immunomodulation: Pathological and therapeutic implications. Nat. Immunol. 2014, 15, 1009-1016. [CrossRef]

95. Moreira, A.; Kahlenberg, S.; Hornsby, P. Therapeutic potential of mesenchymal stem cells for diabetes. J. Mol. Endocrinol. 2017, 59, R109-R120. [CrossRef]

96. Carlsson, P.O.; Schwarcz, E.; Korsgren, O.; Le Blanc, K. Preserved beta-cell function in type 1 diabetes by mesenchymal stromal cells. Diabetes 2015, 64, 587-592. [CrossRef]

97. Jurewicz, M.; Yang, S.; Augello, A.; Godwin, J.G.; Moore, R.F.; Azzi, J.; Fiorina, P.; Atkinson, M.; Sayegh, M.H.; Abdi, R. Congenic mesenchymal stem cell therapy reverses hyperglycemia in experimental type 1 diabetes. Diabetes 2010, 59, 3139-3147. [CrossRef]

98. Cai, J.; Wu, Z.; Xu, X.; Liao, L.; Chen, J.; Huang, L.; Wu, W.; Luo, F.; Wu, C.; Pugliese, A.; et al. Umbilical Cord Mesenchymal Stromal Cell With Autologous Bone Marrow Cell Transplantation in Established Type 1 3Diabetes: A Pilot Randomized Controlled Open-Label Clinical Study to Assess Safety and Impact on Insulin Secretion. Diabetes Care 2016, 39, 149-157. [CrossRef]

99. Maude, S.; Barrett, D.M. Current status of chimeric antigen receptor therapy for haematological malignancies. Br. J. Haematol. 2016, 172, 11-22. [CrossRef]

100. Grupp, S.A.; Kalos, M.; Barrett, D.; Aplenc, R.; Porter, D.L.; Rheingold, S.R.; Teachey, D.T.; Chew, A.; Hauck, B.; Wright, J.F.; et al. Chimeric antigen receptor-modified T cells for acute lymphoid leukemia. N. Engl. J. Med. 2013, 368, 1509-1518. [CrossRef]

101. Yoon, J.; Schmidt, A.; Zhang, A.H.; Konigs, C.; Kim, Y.C.; Scott, D.W. FVIII-specific human chimeric antigen receptor T-regulatory cells suppress T- and B-cell responses to FVIII. Blood 2017, 129, 238-245. [CrossRef]

102. MacDonald, K.G.; Hoeppli, R.E.; Huang, Q.; Gillies, J.; Luciani, D.S.; Orban, P.C.; Broady, R.; Levings, M.K. Alloantigen-specific regulatory T cells generated with a chimeric antigen receptor. J. Clin. Investig. 2016, 126, 1413-1424. [CrossRef]

103. Pierini, A.; Iliopoulou, B.P.; Peiris, H.; Perez-Cruz, M.; Baker, J.; Hsu, K.; Gu, X.; Zheng, P.P.; Erkers, T.; Tang, S.W.; et al. T cells expressing chimeric antigen receptor promote immune tolerance. JCI Insight 2017, 2. [CrossRef]

104. Noyan, F.; Zimmermann, K.; Hardtke-Wolenski, M.; Knoefel, A.; Schulde, E.; Geffers, R.; Hust, M.; Huehn, J.; Galla, M.; Morgan, M.; et al. Prevention of Allograft Rejection by Use of Regulatory T Cells with an MHC-Specific Chimeric Antigen Receptor. Am. J. Transplant. 2017, 17, 917-930. [CrossRef]

105. Fransson, M.; Piras, E.; Burman, J.; Nilsson, B.; Essand, M.; Lu, B.; Harris, R.A.; Magnusson, P.U.; Brittebo, E.; Loskog, A.S. CAR/FoxP3-engineered T regulatory cells target the CNS and suppress EAE upon intranasal delivery. J. Neuroinflamm. 2012, 9, 112. [CrossRef]

106. Skuljec, J.; Chmielewski, M.; Happle, C.; Habener, A.; Busse, M.; Abken, H.; Hansen, G. Chimeric Antigen Receptor-Redirected Regulatory T Cells Suppress Experimental Allergic Airway Inflammation, a Model of Asthma. Front. Immunol. 2017, 8, 1125. [CrossRef] 
107. Kim, Y.C.; Zhang, A.H.; Su, Y.; Rieder, S.A.; Rossi, R.J.; Ettinger, R.A.; Pratt, K.P.; Shevach, E.M.; Scott, D.W. Engineered antigen-specific human regulatory T cells: Immunosuppression of FVIII-specific T- and B-cell responses. Blood 2015, 125, 1107-1115. [CrossRef]

108. Hull, C.M.; Nickolay, L.E.; Estorninho, M.; Richardson, M.W.; Riley, J.L.; Peakman, M.; Maher, J.; Tree, T.I. Generation of human islet-specific regulatory T cells by TCR gene transfer. J. Autoimmun. 2017, 79, 63-73. [CrossRef]

109. Tenspolde, M.; Zimmermann, K.; Weber, L.C.; Hapke, M.; Lieber, M.; Dywicki, J.; Frenzel, A.; Hust, M.; Galla, M.; Buitrago-Molina, L.E.; et al. Regulatory T cells engineered with a novel insulin-specific chimeric antigen receptor as a candidate immunotherapy for type 1 diabetes. J. Autoimmun. 2019. [CrossRef]

110. Balhuizen, A.; Massa, S.; Mathijs, I.; Turatsinze, J.V.; De Vos, J.; Demine, S.; Xavier, C.; Villate, O.; Millard, I.; Egrise, D.; et al. A nanobody-based tracer targeting DPP6 for non-invasive imaging of human pancreatic endocrine cells. Sci. Rep. 2017, 7, 15130. [CrossRef]

111. Burtea, C.; Laurent, S.; Crombez, D.; Delcambre, S.; Sermeus, C.; Millard, I.; Rorive, S.; Flamez, D.; Beckers, M.C.; Salmon, I.; et al. Development of a peptide-functionalized imaging nanoprobe for the targeting of (FXYD2)gammaa as a highly specific biomarker of pancreatic beta cells. Contrast Media Mol. Imaging 2015, 10, 398-412. [CrossRef]

112. Saunders, D.C.; Brissova, M.; Phillips, N.; Shrestha, S.; Walker, J.T.; Aramandla, R.; Poffenberger, G.; Flaherty, D.K.; Weller, K.P.; Pelletier, J.; et al. Ectonucleoside Triphosphate Diphosphohydrolase-3 Antibody Targets Adult Human Pancreatic beta Cells for In Vitro and In Vivo Analysis. Cell Metab. 2019, 29, 745-754. [CrossRef]

113. Brown, K.; DeCoffe, D.; Molcan, E.; Gibson, D.L. Diet-induced dysbiosis of the intestinal microbiota and the effects on immunity and disease. Nutrients 2012, 4, 1095-1119. [CrossRef]

114. Macdonald, T.T.; Monteleone, G. Immunity, inflammation, and allergy in the gut. Science 2005, 307, 1920-1925. [CrossRef]

115. Backhed, F.; Ley, R.E.; Sonnenburg, J.L.; Peterson, D.A.; Gordon, J.I. Host-bacterial mutualism in the human intestine. Science 2005, 307, 1915-1920. [CrossRef]

116. Quigley, E.M. Gut bacteria in health and disease. Gastroenterol. Hepatol. 2013, 9, 560-569.

117. Wichmann, A.; Allahyar, A.; Greiner, T.U.; Plovier, H.; Lunden, G.O.; Larsson, T.; Drucker, D.J.; Delzenne, N.M.; Cani, P.D.; Backhed, F. Microbial modulation of energy availability in the colon regulates intestinal transit. Cell Host Microbe 2013, 14, 582-590. [CrossRef]

118. Sanz, Y.; Olivares, M.; Moya-Perez, A.; Agostoni, C. Understanding the role of gut microbiome in metabolic disease risk. Pediatr. Res. 2015, 77, 236-244. [CrossRef]

119. Aljutaily, T.; Consuegra-Fernandez, M.; Aranda, F.; Lozano, F.; Huarte, E. Gut microbiota metabolites for sweetening type I diabetes. Cell. Mol. Immunol. 2018, 15, 92-95. [CrossRef]

120. Vaishnava, S.; Behrendt, C.L.; Ismail, A.S.; Eckmann, L.; Hooper, L.V. Paneth cells directly sense gut commensals and maintain homeostasis at the intestinal host-microbial interface. Proc. Natl. Acad. Sci. USA 2008, 105, 20858-20863. [CrossRef]

121. Barnes, M.J.; Powrie, F. Regulatory T cells reinforce intestinal homeostasis. Immunity 2009, 31, 401-411. [CrossRef] [PubMed]

122. Sekirov, I.; Russell, S.L.; Antunes, L.C.; Finlay, B.B. Gut microbiota in health and disease. Physiol. Rev. 2010, 90, 859-904. [CrossRef] [PubMed]

123. Paun, A.; Yau, C.; Danska, J.S. The Influence of the Microbiome on Type 1 Diabetes. J. Immunol. 2017, 198, 590-595. [CrossRef] [PubMed]

124. Vaarala, O.; Atkinson, M.A.; Neu, J. The "perfect storm" for type 1 diabetes: The complex interplay between intestinal microbiota, gut permeability, and mucosal immunity. Diabetes 2008, 57, 2555-2562. [CrossRef]

125. Pellegrini, S.; Sordi, V.; Bolla, A.M.; Saita, D.; Ferrarese, R.; Canducci, F.; Clementi, M.; Invernizzi, F.; Mariani, A.; Bonfanti, R.; et al. Duodenal Mucosa of Patients With Type 1 Diabetes Shows Distinctive Inflammatory Profile and Microbiota. J. Clin. Endocrinol. Metab. 2017, 102, 1468-1477. [CrossRef]

126. Allin, K.H.; Tremaroli, V.; Caesar, R.; Jensen, B.A.H.; Damgaard, M.T.F.; Bahl, M.I.; Licht, T.R.; Hansen, T.H.; Nielsen, T.; Dantoft, T.M.; et al. Aberrant intestinal microbiota in individuals with prediabetes. Diabetologia 2018, 61, 810-820. [CrossRef] 
127. Giongo, A.; Gano, K.A.; Crabb, D.B.; Mukherjee, N.; Novelo, L.L.; Casella, G.; Drew, J.C.; Ilonen, J.; Knip, M.; Hyoty, H.; et al. Toward defining the autoimmune microbiome for type 1 diabetes. ISME J. 2011, 5, 82-91. [CrossRef]

128. Huang, Y.; Li, S.C.; Hu, J.; Ruan, H.B.; Guo, H.M.; Zhang, H.H.; Wang, X.; Pei, Y.F.; Pan, Y.; Fang, C. Gut microbiota profiling in Han Chinese with type 1 diabetes. Diabetes Res. Clin. Pract. 2018, 141, 256-263. [CrossRef]

129. Brown, C.T.; Davis-Richardson, A.G.; Giongo, A.; Gano, K.A.; Crabb, D.B.; Mukherjee, N.; Casella, G.; Drew, J.C.; Ilonen, J.; Knip, M.; et al. Gut microbiome metagenomics analysis suggests a functional model for the development of autoimmunity for type 1 diabetes. PLoS ONE 2011, 6, e25792. [CrossRef]

130. Everard, A.; Belzer, C.; Geurts, L.; Ouwerkerk, J.P.; Druart, C.; Bindels, L.B.; Guiot, Y.; Derrien, M.; Muccioli, G.G.; Delzenne, N.M.; et al. Cross-talk between Akkermansia muciniphila and intestinal epithelium controls diet-induced obesity. Proc. Natl. Acad. Sci. USA 2013, 110, 9066-9071. [CrossRef]

131. Derrien, M.; Belzer, C.; de Vos, W.M. Akkermansia muciniphila and its role in regulating host functions. Microb. Pathog. 2017, 106, 171-181. [CrossRef]

132. Shin, N.R.; Lee, J.C.; Lee, H.Y.; Kim, M.S.; Whon, T.W.; Lee, M.S.; Bae, J.W. An increase in the Akkermansia spp. population induced by metformin treatment improves glucose homeostasis in diet-induced obese mice. Gut 2014, 63, 727-735. [CrossRef]

133. Tanca, A.; Palomba, A.; Fraumene, C.; Manghina, V.; Silverman, M.; Uzzau, S. Clostridial Butyrate Biosynthesis Enzymes Are Significantly Depleted in the Gut Microbiota of Nonobese Diabetic Mice. mSphere 2018, 3. [CrossRef]

134. Kostic, A.D.; Gevers, D.; Siljander, H.; Vatanen, T.; Hyotylainen, T.; Hamalainen, A.M.; Peet, A.; Tillmann, V.; Poho, P.; Mattila, I.; et al. The dynamics of the human infant gut microbiome in development and in progression toward type 1 diabetes. Cell Host Microbe 2015, 17, 260-273. [CrossRef]

135. Kriegel, M.A.; Sefik, E.; Hill, J.A.; Wu, H.J.; Benoist, C.; Mathis, D. Naturally transmitted segmented filamentous bacteria segregate with diabetes protection in nonobese diabetic mice. Proc. Natl. Acad. Sci. USA 2011, 108, 11548-11553. [CrossRef]

136. Marco, M.L.; Heeney, D.; Binda, S.; Cifelli, C.J.; Cotter, P.D.; Foligne, B.; Ganzle, M.; Kort, R.; Pasin, G.; Pihlanto, A.; et al. Health benefits of fermented foods: Microbiota and beyond. Curr. Opin. Biotechnol. 2017, 44, 94-102. [CrossRef]

137. Macia, L.; Thorburn, A.N.; Binge, L.C.; Marino, E.; Rogers, K.E.; Maslowski, K.M.; Vieira, A.T.; Kranich, J.; Mackay, C.R. Microbial influences on epithelial integrity and immune function as a basis for inflammatory diseases. Immunol. Rev. 2012, 245, 164-176. [CrossRef]

138. Vrieze, A.; Van Nood, E.; Holleman, F.; Salojarvi, J.; Kootte, R.S.; Bartelsman, J.F.; Dallinga-Thie, G.M.; Ackermans, M.T.; Serlie, M.J.; Oozeer, R.; et al. Transfer of intestinal microbiota from lean donors increases insulin sensitivity in individuals with metabolic syndrome. Gastroenterology 2012, 143, 913-916. [CrossRef]

139. Smits, L.P.; Bouter, K.E.; de Vos, W.M.; Borody, T.J.; Nieuwdorp, M. Therapeutic potential of fecal microbiota transplantation. Gastroenterology 2013, 145, 946-953. [CrossRef]

140. He, C.; Shan, Y.; Song, W. Targeting gut microbiota as a possible therapy for diabetes. Nutr. Res. 2015, 35, 361-367. [CrossRef]

141. Gomes, A.C.; Bueno, A.A.; de Souza, R.G.; Mota, J.F. Gut microbiota, probiotics and diabetes. Nutr. J. 2014, 13, 60. [CrossRef]

142. Mishra, S.P.; Wang, S.; Nagpal, R.; Miller, B.; Singh, R.; Taraphder, S.; Yadav, H. Probiotics and Prebiotics for the Amelioration of Type 1 Diabetes: Present and Future Perspectives. Microorganisms 2019, 7, 67. [CrossRef]

143. Zhao, S.; Liu, W.; Wang, J.; Shi, J.; Sun, Y.; Wang, W.; Ning, G.; Liu, R.; Hong, J. Akkermansia muciniphila improves metabolic profiles by reducing inflammation in chow diet-fed mice. J. Mol. Endocrinol. 2017, 58, 1-14. [CrossRef]

144. Depommier, C.; Everard, A.; Druart, C.; Plovier, H.; Van Hul, M.; Vieira-Silva, S.; Falony, G.; Raes, J.; Maiter, D.; Delzenne, N.M.; et al. Supplementation with Akkermansia muciniphila in overweight and obese human volunteers: A proof-of-concept exploratory study. Nat. Med. 2019, 25, 1096-1103. [CrossRef]

145. Wang, L.; Wu, Y.; Zhuang, L.; Chen, X.; Min, H.; Song, S.; Liang, Q.; Li, A.D.; Gao, Q. Puerarin prevents high-fat diet-induced obesity by enriching Akkermansia muciniphila in the gut microbiota of mice. PLOS ONE 2019, 14, e0218490. [CrossRef]

146. Villarino, A.V.; Kanno, Y.; O'Shea, J.J. Mechanisms and consequences of Jak-STAT signaling in the immune system. Nat. Immunol. 2017, 18, 374-384. [CrossRef] 
147. Rawlings, J.S.; Rosler, K.M.; Harrison, D.A. The JAK/STAT signaling pathway. J. Cell Sci. 2004, 117, 1281-1283. [CrossRef]

148. Howell, M.D.; Fitzsimons, C.; Smith, P.A. JAK/STAT inhibitors and other small molecule cytokine antagonists for the treatment of allergic disease. Ann. Allergy Asthma Immunol. 2018, 120, 367-375. [CrossRef]

149. Ferreira, R.C.; Guo, H.; Coulson, R.M.; Smyth, D.J.; Pekalski, M.L.; Burren, O.S.; Cutler, A.J.; Doecke, J.D.; Flint, S.; McKinney, E.F.; et al. A type I interferon transcriptional signature precedes autoimmunity in children genetically at risk for type 1 diabetes. Diabetes 2014, 63, 2538-2550. [CrossRef]

150. Huang, X.; Yuang, J.; Goddard, A.; Foulis, A.; James, R.F.; Lernmark, A.; Pujol-Borrell, R.; Rabinovitch, A.; Somoza, N.; Stewart, T.A. Interferon expression in the pancreases of patients with type I diabetes. Diabetes 1995, 44, 658-664. [CrossRef]

151. Kallionpaa, H.; Elo, L.L.; Laajala, E.; Mykkanen, J.; Ricano-Ponce, I.; Vaarma, M.; Laajala, T.D.; Hyoty, H.; Ilonen, J.; Veijola, R.; et al. Innate immune activity is detected prior to seroconversion in children with HLA-conferred type 1 diabetes susceptibility. Diabetes 2014, 63, 2402-2414. [CrossRef] [PubMed]

152. Foulis, A.K.; Farquharson, M.A.; Meager, A. Immunoreactive alpha-interferon in insulin-secreting beta cells in type 1 diabetes mellitus. Lancet 1987, 2, 1423-1427. [CrossRef]

153. Richardson, S.J.; Rodriguez-Calvo, T.; Gerling, I.C.; Mathews, C.E.; Kaddis, J.S.; Russell, M.A.; Zeissler, M.; Leete, P.; Krogvold, L.; Dahl-Jorgensen, K.; et al. Islet cell hyperexpression of HLA class I antigens: A defining feature in type 1 diabetes. Diabetologia 2016, 59, 2448-2458. [CrossRef] [PubMed]

154. Marroqui, L.; Dos Santos, R.S.; Op de Beeck, A.; Coomans de Brachene, A.; Marselli, L.; Marchetti, P.; Eizirik, D.L. Interferon-alpha mediates human beta cell HLA class I overexpression, endoplasmic reticulum stress and apoptosis, three hallmarks of early human type 1 diabetes. Diabetologia 2017, 60, 656-667. [CrossRef] [PubMed]

155. Tao, J.H.; Zou, Y.F.; Feng, X.L.; Li, J.; Wang, F.; Pan, F.M.; Ye, D.Q. Meta-analysis of TYK2 gene polymorphisms association with susceptibility to autoimmune and inflammatory diseases. Mol. Biol. Rep. 2011, 38, 4663-4672. [CrossRef] [PubMed]

156. Wallace, C.; Smyth, D.J.; Maisuria-Armer, M.; Walker, N.M.; Todd, J.A.; Clayton, D.G. The imprinted DLK1-MEG3 gene region on chromosome 14q32.2 alters susceptibility to type 1 diabetes. Nat. Genet. 2010, 42, 68-71. [CrossRef]

157. Roep, B.O.; Kleijwegt, F.S.; van Halteren, A.G.; Bonato, V.; Boggi, U.; Vendrame, F.; Marchetti, P.; Dotta, F. Islet inflammation and CXCL10 in recent-onset type 1 diabetes. Clin. Exp. Immunol. 2010, 159, 338-343. [CrossRef]

158. Sarkar, S.A.; Lee, C.E.; Victorino, F.; Nguyen, T.T.; Walters, J.A.; Burrack, A.; Eberlein, J.; Hildemann, S.K.; Homann, D. Expression and regulation of chemokines in murine and human type 1 diabetes. Diabetes 2012, 61, 436-446. [CrossRef]

159. Morimoto, J.; Yoneyama, H.; Shimada, A.; Shigihara, T.; Yamada, S.; Oikawa, Y.; Matsushima, K.; Saruta, T.; Narumi, S. CXC chemokine ligand 10 neutralization suppresses the occurrence of diabetes in nonobese diabetic mice through enhanced beta cell proliferation without affecting insulitis. J. Immunol. 2004, 173, 7017-7024. [CrossRef]

160. Savinov, A.Y.; Wong, F.S.; Chervonsky, A.V. IFN-gamma affects homing of diabetogenic T cells. J. Immunol. 2001, 167, 6637-6643. [CrossRef]

161. Barroso-Sousa, R.; Ott, P.A.; Hodi, F.S.; Kaiser, U.B.; Tolaney, S.M.; Min, L. Endocrine dysfunction induced by immune checkpoint inhibitors: Practical recommendations for diagnosis and clinical management. Cancer 2018, 124, 1111-1121. [CrossRef]

162. Cukier, P.; Santini, F.C.; Scaranti, M.; Hoff, A.O. Endocrine side effects of cancer immunotherapy. Endocr. Relat. Cancer 2017, 24, T331-T347. [CrossRef]

163. Stamatouli, A.M.; Quandt, Z.; Perdigoto, A.L.; Clark, P.L.; Kluger, H.; Weiss, S.A.; Gettinger, S.; Sznol, M.; Young, A.; Rushakoff, R.; et al. Collateral Damage: Insulin-Dependent Diabetes Induced With Checkpoint Inhibitors. Diabetes 2018, 67, 1471-1480. [CrossRef]

164. Ansari, M.J.; Salama, A.D.; Chitnis, T.; Smith, R.N.; Yagita, H.; Akiba, H.; Yamazaki, T.; Azuma, M.; Iwai, H.; Khoury, S.J.; et al. The programmed death-1 (PD-1) pathway regulates autoimmune diabetes in nonobese diabetic (NOD) mice. J. Exp. Med. 2003, 198, 63-69. [CrossRef]

165. Coomans de Brachene, A.; Dos Santos, R.S.; Marroqui, L.; Colli, M.L.; Marselli, L.; Mirmira, R.G.; Marchetti, P.; Eizirik, D.L. IFN-alpha induces a preferential long-lasting expression of MHC class I in human pancreatic beta cells. Diabetologia 2018, 61, 636-640. [CrossRef] 
166. Trivedi, P.M.; Graham, K.L.; Scott, N.A.; Jenkins, M.R.; Majaw, S.; Sutherland, R.M.; Fynch, S.; Lew, A.M.; Burns, C.J.; Krishnamurthy, B.; et al. Repurposed JAK1/JAK2 Inhibitor Reverses Established Autoimmune Insulitis in NOD Mice. Diabetes 2017, 66, 1650-1660. [CrossRef]

167. Kostromina, E.; Gustavsson, N.; Wang, X.; Lim, C.Y.; Radda, G.K.; Li, C.; Han, W. Glucose intolerance and impaired insulin secretion in pancreas-specific signal transducer and activator of transcription-3 knockout mice are associated with microvascular alterations in the pancreas. Endocrinology 2010, 151, 2050-2059. [CrossRef]

168. Kostromina, E.; Wang, X.; Han, W. Altered islet morphology but normal islet secretory function in vitro in a mouse model with microvascular alterations in the pancreas. PLoS ONE 2013, 8, e71277. [CrossRef]

169. Lee, J.Y.; Gavrilova, O.; Davani, B.; Na, R.; Robinson, G.W.; Hennighausen, L. The transcription factors $\mathrm{Stat} 5 \mathrm{a} / \mathrm{b}$ are not required for islet development but modulate pancreatic beta-cell physiology upon aging. Biochim. Biophys. Acta 2007, 1773, 1455-1461. [CrossRef]

170. Bach, J.F. Insulin-dependent diabetes mellitus as an autoimmune disease. Endocr. Rev. 1994, 15, 516-542. [CrossRef]

171. Eisenbarth, G.S. Type 1 diabetes: Molecular, cellular and clinical immunology. Adv. Exp. Med. Biol. 2004, 552, 306-310.

172. Gomez-Tourino, I.; Arif, S.; Eichmann, M.; Peakman, M. T cells in type 1 diabetes: Instructors, regulators and effectors: A comprehensive review. J. Autoimmun. 2016, 66, 7-16. [CrossRef]

173. Smith, E.L.; Peakman, M. Peptide Immunotherapy for Type 1 Diabetes-Clinical Advances. Front. Immunol. 2018, 9, 392. [CrossRef]

(C) 2019 by the authors. Licensee MDPI, Basel, Switzerland. This article is an open access article distributed under the terms and conditions of the Creative Commons Attribution (CC BY) license (http://creativecommons.org/licenses/by/4.0/). 